\title{
Design and synthesis of tris[bis(benzylammonium)aryl]phosphines with bulky meta-substituents
}

\author{
Robert Kreiter, Robertus J. M. Klein Gebbink and Gerard van Koten* \\ Department of Metal-Mediated Synthesis, Debye Institute, Utrecht University, Padualaan 8, NL-3784 CH Utrecht, The Netherlands
}

Received 18 November 2002; revised 29 January 2003; accepted 4 February 2003

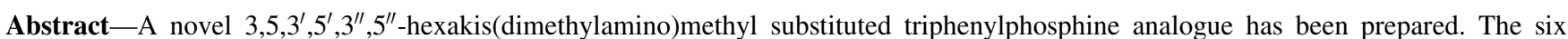
amine functionalities of the corresponding phosphine oxide and sulfide were alkylated quantitatively with methyl iodide and benzyl bromide, as well as with G1 and G2 Fréchet dendrons to afford the respective hexa-ammonium triarylphosphine oxides and sulfides. The phosphine sulfide derivatives were deprotected with $\mathrm{P}(n-\mathrm{Bu})_{3}$ to afford a series of hexa-ammonium triarylphosphines that range from small molecules to first and second generation dendrimers (MW up to 5451.44). Upon formation of the hexa-ammonium salt a clear shift in ${ }^{31} \mathrm{P}$ NMR is observed, indicative for opening of the $\mathrm{C}-\mathrm{P}-\mathrm{C}$ angle of the triaryl phosphine. Calculations on the hexacationic phosphines show an increased barrier of rotation around the $\mathrm{P}-\mathrm{C}$ (aryl) bond with increasing size of the $N$-substituents. The calculated structure of the G2-dendron alkylated hexa-ammonium triarylphosphine shows that this dendritic phosphine has a disc-like rather than a cone-like structure, with an estimated cone angle of approximately $180^{\circ}$ (C) 2003 Elsevier Science Ltd. All rights reserved.
\end{abstract}

\section{Introduction}

Dendrimers are widely applied in coordination chemistry and catalysis. ${ }^{1,2}$ In most of these cases, ligands are attached to an (inert) dendrimer backbone, at the periphery, at the core, or at the branches of the dendrimer. Homogeneous catalysts based on dendrimers functionalized with phosphines at the periphery were reported by many authors. ${ }^{3}$ Illustrative examples were developed in the groups of Van Leeuwen, ${ }^{4}$ Reetz, ${ }^{5}$ Togni, ${ }^{6}$ and Majoral, ${ }^{7}$ as well as in our group. ${ }^{8}$ Phosphine ligands of which the phosphorus center is part of the dendrimer backbone, were reported by the groups of Dubois and Kakkar, respectively. ${ }^{9}$ Furthermore, dendronenlarged diphosphines derived from DPPF, ${ }^{10} \mathrm{DPPE},{ }^{11}$ and BINAP $^{12}$ were studied. Surprisingly, dendron attachment to monodentate phosphines has attracted much less attention. Catalano reported on (mono-dendron)diphenylphosphines $\mathrm{PPh}_{2}(\mathrm{G} 1)$, and $\mathrm{PPh}_{2}(\mathrm{G} 2)$, where $\mathrm{G} 1$ and $\mathrm{G} 2$ are first and second generation Fréchet-type dendrons, respectively. ${ }^{13}$ More recently, Tsuji et al. described the synthesis of functionalized triphenylphosphines having a dendron on two of the three phenyl rings, as well as DPPE functionalized with a dendron on each of the four aryl rings. ${ }^{14}$ Platinum(0) complexes of the mono-dentate ligands were studied and revealed a preference for the formation of $\mathrm{ML}_{3}$

Keywords: dendrimers; ammonium salt; phosphine ligand; Dendriphos; cone angle.

* Corresponding author. Tel.: +31-30-2531813; fax: +31-30-2523615; e-mail: g.vankoten@chem.uu.nl type complexes, even in the presence of excess ligand. Attachment of carbosilane dendrons at the para-position of all three aryl rings of triphenylphosphine was reported by the group of Van Leeuwen. ${ }^{10}$

Recently, we reported on multicationic dendrimers based on tetrahedral tetrakis(mono- and bis[(dimethylamino)methyl]phenyl)silane core molecules. To these core molecules, dendrons were attached by a quaternization reaction with benzylic bromides derived from Fréchet-type dendritic wedges. ${ }^{15}$ This yielded a new class of tetra- and

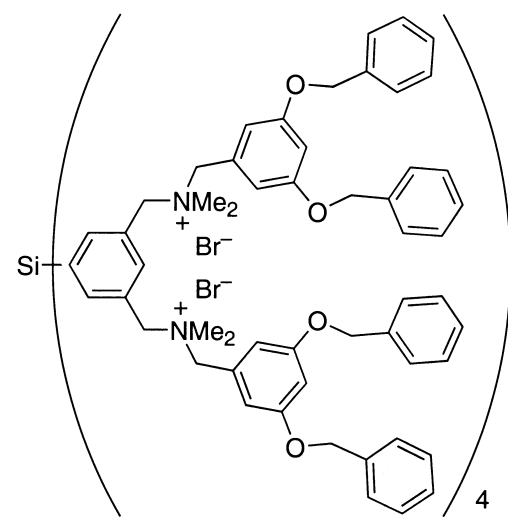

$\left[\mathrm{Si}(\mathrm{NCN})_{4} \cdot(\mathrm{G} 1)_{8}\right] \mathrm{Br}_{8}$

Figure 1. Octacationic dendrimer based on a tetrakis(3,5-bis[(dimethylamino)methyl]phenyl)silane core molecule. 
octa-cationic dendrimers (for an example see Figure 1), which were successfully applied as phase-transfer catalysts in $\mathrm{S}_{\mathrm{N}} 2$ type reactions. Furthermore, it was shown that these oligo-cationic dendrimers can serve as host molecules for the non-covalent attachment of a predefined number of anions, such as methyl orange, pyrene-1-sulfate, and $\mathrm{PF}_{6}^{-}$. Moreover, these dendrimers were applied as a soluble supporting material for anionic organometallic complexes. ${ }^{16}$ For example, an assembly of eight anionic organometallic complexes and a single octa-cationic dendritic support could be constructed via non-covalent interactions, purified by dialysis and subsequently used as a Lewis acid catalyst in an aldol condensation.

In the present study our attention is directed towards the influence of the stereochemistry of the core molecule on the binding ability of this kind of oligo-cationic, dendritic supports. To this end we selected the phosphorus atom of triphenylphosphine which, like the Si-center in the dendrimers described above, has a stable tetrahedral configuration, but has a lone pair instead of a fourth substituent. Here we report the synthesis of a novel tris(3,5bis[(dimethylamino)methyl]aryl)phosphine, providing an interesting combination of one soft and six hard Lewis bases. Furthermore, we present the $N$-alkylation of this triarylphosphine core molecule to afford several hexaammonium triarylphosphine derivatives. These hexacationic phosphines are potentially useful as supporting material for a variety of anions, whilst retaining their phosphine donor ability for coordination to metal sites or for reaction with electrophiles.

\section{Results and discussion}

\subsection{Synthesis}

A common route in the preparation of triarylphosphines involves the coupling of an aryl-Grignard or -lithium reagent to a phosphorus trihalide. We chose to react 1-bromo-3,5-bis[(dimethylamino)methyl]benzene ( $\mathrm{Br}-\mathrm{NCN}$, 1) ${ }^{17}$ with 2 equiv. of $t$-BuLi to give the 5-lithio-derivative. Subsequent addition of $1 / 3$ equiv. of phosphorus tribromide resulted in the formation of tris(3,5-bis[(dimethylamino)methyl]phenyl)phosphine $\left(\mathrm{P}(\mathrm{NCN})_{3}, 2\right)$ (Scheme 1). After extraction with $\mathrm{CH}_{2} \mathrm{Cl}_{2}$ and evaporation of all volatiles, crude 2 was obtained as a yellow oil. In order to protect the
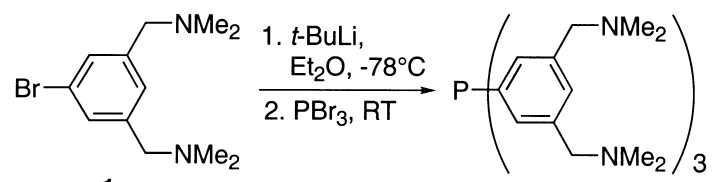

2

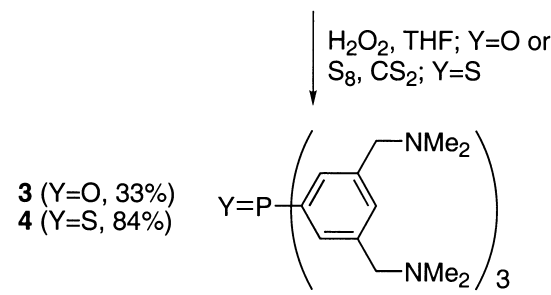

Scheme 1. Synthesis of tris(3,5-bis[(dimethylamino)methyl]phenyl)phosphine oxide (3) and sulfide (4). phosphorus atom and to enable selective $\mathrm{N}$-alkylation chemistry, crude 2 was first either oxidized with $\mathrm{H}_{2} \mathrm{O}_{2}$ in THF, to afford phosphine oxide $3\left(\mathrm{O}=\mathrm{P}(\mathrm{NCN})_{3}\right)$, or reacted with sulfur in $\mathrm{CS}_{2}$ to afford phosphine sulfide $4\left(\mathrm{~S}=\mathrm{P}(\mathrm{NCN})_{3}\right)$ (Scheme 1). These protected phosphines were recrystallized from hexane (for 3), or washed with hexane (in the case of 4) to afford off-white solids in reasonable overall yields.

$\mathrm{O}=\mathrm{P}(\mathrm{NCN})_{3}(3)$ and $\mathrm{S}=\mathrm{P}(\mathrm{NCN})_{3}$ (4) were alkylated with $\mathrm{MeI}$ in $\mathrm{CH}_{2} \mathrm{Cl}_{2}$ at room temperature (Scheme 2). The respective products precipitated from the reaction mixtures as light yellow powders, which could be filtered off. Precipitation from $\mathrm{MeOH}$ with $\mathrm{Et}_{2} \mathrm{O}$ afforded pure hexaammonium triaryl phosphine oxide 5a $\left(\left[\mathrm{O}=\mathrm{P}(\mathrm{NCN})_{3}\right.\right.$. $\left.\left.\mathrm{Me}_{6}\right] \mathrm{I}_{6}\right)$ and sulfide $\mathbf{6 a}\left(\left[\mathrm{S}=\mathrm{P}(\mathrm{NCN})_{3} \cdot \mathrm{Me}_{6}\right] \mathrm{I}_{6}\right)$. These MeI salts are highly soluble in $\mathrm{H}_{2} \mathrm{O}$ and moderately soluble in $\mathrm{MeOH}$, but insoluble in less polar organic solvents, such as $\mathrm{CH}_{2} \mathrm{Cl}_{2}$ and hexane. Likewise, 3 and $\mathbf{4}$ were converted with benzyl bromide in $\mathrm{CH}_{2} \mathrm{Cl}_{2}$ at room temperature into the corresponding ammonium salts $\mathbf{5 b}\left(\left[\mathrm{O}=\mathrm{P}(\mathrm{NCN})_{3} \cdot \mathrm{Bz}_{6}\right] \mathrm{Br}_{6}\right)$ and $\mathbf{6 b}\left(\left[\mathrm{S}=\mathrm{P}(\mathrm{NCN})_{3} \cdot \mathrm{Bz}_{6}\right] \mathrm{Br}_{6}\right)$ (Scheme 2). Both salts have solubilities similar to $\mathbf{5 a}$ and $\mathbf{6 a}$, but are less soluble in $\mathrm{H}_{2} \mathrm{O}$. These alkylation reactions occur readily at room temperature and are quantitative. In spite of this, the products are obtained in lower although still reasonable yields, which is mainly caused by the required purification procedure.

To obtain the hexacationic, dendritic phosphine oxides $\mathbf{5 c}$ $\left(\left[\mathrm{O}=\mathrm{P}(\mathrm{NCN})_{3} \cdot(\mathrm{G} 1)_{6}\right] \mathrm{Br}_{6}\right)$ and $\mathbf{5 d}\left(\left[\mathrm{O}=\mathrm{P}(\mathrm{NCN})_{3} \cdot(\mathrm{G} 2)_{6}\right]-\right.$ $\left.\mathrm{Br}_{6}\right)$ and sulfides $\mathbf{6 c}\left(\left[\mathrm{S}=\mathrm{P}(\mathrm{NCN})_{3} \cdot(\mathrm{G} 1)_{6}\right] \mathrm{Br}_{6}\right)$ and $\mathbf{6 d}$ $\left(\left[\mathrm{S}=\mathrm{P}(\mathrm{NCN})_{3} \cdot(\mathrm{G} 2)_{6}\right] \mathrm{Br}_{6}\right), 3$ and 4 were reacted with the corresponding benzylic bromides of the first $(\mathrm{G} 1-\mathrm{Br})$ and second $(\mathrm{G} 2-\mathrm{Br})$ generation Fréchet-type dendritic wedges ${ }^{18}$ in $\mathrm{CH}_{2} \mathrm{Cl}_{2}$ at room temperature (Scheme 2). The products were purified by repeated precipitation with $\mathrm{Et}_{2} \mathrm{O}$ from $\mathrm{CH}_{2} \mathrm{Cl}_{2}$ and isolated as white solids. Like the reactions with the smaller alkyl halides, these reactions were quantitative, and occurred readily at room temperature. The isolated yields were lowered by the precipitation steps applied in the purification of the products. These dendritic salts are highly soluble in chlorinated organic solvents, but are insoluble in $\mathrm{Et}_{2} \mathrm{O}$ and alkanes. Furthermore, the $\mathrm{G} 1$ derivatives $(\mathbf{5 c}, \mathbf{6 c})$ are slightly soluble in $\mathrm{MeOH}$, whereas the $\mathrm{G} 2$ derivatives (5d, 6d) are essentially insoluble in this solvent. These reactions demonstrate that starting from a single amine substituted core molecule and a series of alkyl and benzyl halides, hexacationic compounds can be prepared, varying from small molecules $(\mathrm{MW}=1456.48)$ to dendrimers of different generations (MW up to 5451.44). Depending on the $N$-substituent these compounds were found to be soluble in a range of solvents of different polarity. To investigate whether the dendritic salts are suitable hosts for larger anions, methyl orange (MO) was exchanged for the bromide counterions of $\left[\mathrm{O}=\mathrm{P}(\mathrm{NCN})_{3} \cdot(\mathrm{G} 1)_{6}\right] \mathrm{Br}_{6}$ in a preliminary experiment. This experiment showed quantitative incorporation of MO, and confirmed the ability of these dendrimers to serve as host molecules.

Deprotection of the phosphorus atom in $\mathbf{5 a}-\mathbf{d}$ and $\mathbf{6 a}-\mathbf{d}$ was attempted via several different approaches. Standard methods in phosphine oxide reduction, such as refluxing $\left[\mathrm{O}=\mathrm{P}(\mathrm{NCN})_{3} \cdot(\mathrm{G1})_{6}\right] \mathrm{Br}_{6}(\mathbf{5 c})$ in a mixture of $\mathrm{HSiCl}_{3} / \mathrm{NEt}_{3} /$ 


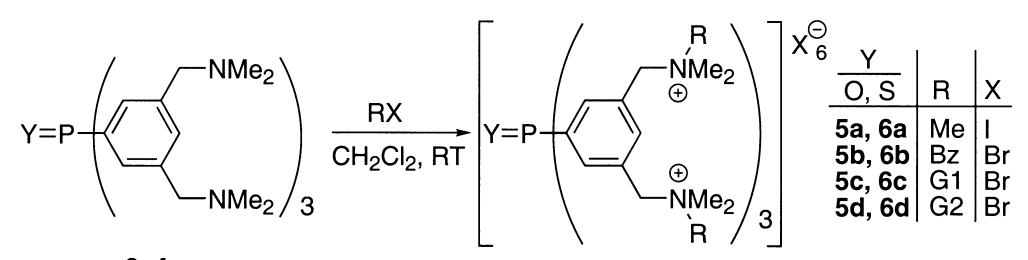

3,4

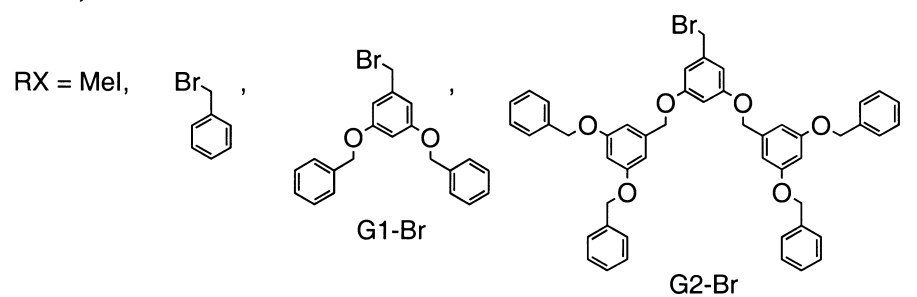

Scheme 2. Alkylation of $\mathbf{3}$ and $\mathbf{4}$ to afford a range of hexa-ammonium salts.

$\mathrm{C}_{6} \mathrm{H}_{6}$ did not result in reduction. Other methods such as treatment of one of the oxides $\mathbf{5 a - d}$ with bis(catecholato$O, O^{\prime}$ )diboron and Wilkinson's catalyst in $\mathrm{CH}_{2} \mathrm{Cl}_{2}$, DIBAL$\mathrm{H}$ in $\mathrm{CH}_{2} \mathrm{Cl}_{2}$, or Raney $\mathrm{Ni}$ in $\mathrm{MeOH}$ also did not yield the free phosphines. Each time, the hexacationic phosphine oxides were recovered from the reaction mixture, which points to their high stability under severe conditions. For the phosphine sulfides $\mathbf{6 a}-\mathbf{d}$, methods like reaction with sodium naphthalenide, treatment with $\mathrm{Br}_{2}$ in $\mathrm{Et}_{2} \mathrm{O}$, or heating in pure $\mathrm{P}(n-\mathrm{Bu})_{3}$ did not result in reduction to the free phosphine. Obviously, in the latter case this was due to insolubility of the starting material in $\mathrm{P}(n-\mathrm{Bu})_{3}$. The hexacationic, dendritic phosphine sulfide $\left[\mathrm{S}=\mathrm{P}(\mathrm{NCN})_{3}\right.$. $\left.(\mathrm{G} 1)_{6}\right] \mathrm{Br}_{6}$ (6c) could, however, be reduced to the free phosphine following a procedure reported by Gilbertson et al., which involves sulfur alkylation with MeOTf and subsequent deprotection with HMPT. ${ }^{19}$ Whereas this procedure resulted in reduction of the phosphine sulfide to the free phosphine, exchange of the bromide counterions for triflate ions also occurred, affording $\left[\mathrm{P}(\mathrm{NCN})_{3} \cdot(\mathrm{G1})_{6}\right](\mathrm{OTf})_{6}$ (7). Because of the toxicity of both reagents (MeOTf and HMPT) we pursued, in parallel, another method involving less harmful reagents, and returned to reduction of the phosphine sulfides with $\mathrm{P}(n-\mathrm{Bu})_{3}$. Finally, it appeared that reduction of phosphine sulfides $\mathbf{6 a}-\mathbf{d}$ proceeded smoothly in a refluxing, homogeneous 2:1 mixture of $\mathrm{MeOH}$ and $\mathrm{P}(n-$ $\mathrm{Bu})_{3}$ (Scheme 3). After removal of the volatiles the obtained crude phosphines $\mathbf{8 a}-\mathbf{d}$ were purified by precipitation with $\mathrm{Et}_{2} \mathrm{O}$ from $\mathrm{MeOH}$, affording light yellow (8a) to white solids $(\mathbf{8 b}-\mathbf{d})$. We call this novel class of dendritic phosphines Dendriphos by analogy with other common names for phosphines.

\subsection{Characterization}

Mass spectrometry (nano-ESI) was performed to confirm the molecular mass of the novel hexa-ammonium phosphine oxides and sulfides. For all the hexacationic species, ionization via loss of counterions was observed. In the mass spectrum of $\mathbf{5 a}$ peaks for $\left[\mathrm{M}-\mathrm{I}^{-}\right]^{+},\left[\mathrm{M}-2 \mathrm{I}^{-}\right]^{2+}$, $\left[\mathrm{M}-3 \mathrm{I}^{-}\right]^{3+},\left[\mathrm{M}-4 \mathrm{I}^{-}\right]^{4+}$, and in the spectrum of $6 \mathbf{a}$ peaks for $\left[\mathrm{M}-\mathrm{I}^{-}\right]^{+},\left[\mathrm{M}-2 \mathrm{I}^{-}\right]^{2+},\left[\mathrm{M}-3 \mathrm{I}^{-}\right]^{3+},\left[\mathrm{M}-4 \mathrm{I}^{-}\right]^{4+}$, $[\mathrm{M}-5 \mathrm{I}]^{5+}$, and $\left[\mathrm{M}-6 \mathrm{I}^{-}\right]^{6+}$ were observed. For $\mathbf{5 b}, \mathbf{6 b}$, 5c, and $6 \mathbf{c}\left[\mathrm{M}-2 \mathrm{Br}^{-}\right]^{2+},\left[\mathrm{M}-3 \mathrm{Br}^{-}\right]^{3+},\left[\mathrm{M}-4 \mathrm{Br}^{-}\right]^{4+}$ were observed, while for $\mathbf{5 d}$ and $\mathbf{6 d}\left[\mathrm{M}-3 \mathrm{Br}^{-}\right]^{3+}$ and $\left[\mathrm{M}-4 \mathrm{Br}^{-}\right]^{4+}$ could be identified. In these spectra the base peak is usually the $\left[\mathrm{M}-3 \mathrm{X}^{-}\right]^{3+}$ or $\left[\mathrm{M}-4 \mathrm{X}^{-}\right]^{4+}$ species (for a representative spectrum of $\mathbf{6 d}$ see Figure 2). For the dendritic salts $(\mathbf{5 c}, \mathbf{d}, \mathbf{6 c}, \mathbf{d})$ additional ion peaks are observed at lower $m / z$ values than the molecular ion peaks. This could point to (unexpected) fragmentation or degradation of the Fréchet wedges. To investigate whether these additional ions result from a fragmentation reaction, the cone voltage was lowered to very low values $(10 \mathrm{~V})$. As no change in the mass spectrum was observed, it was concluded that the degradation does not occur due to the cone voltage, but results from the applied capillary voltage in the nanoelectrospray mass spectrometer.

Mass analysis (nano-ESI) of the free phosphines $8 \mathbf{a}-\mathbf{d}$ afforded comparable results. The mass spectrum of $\mathbf{8 c}$ was obtained as the phosphine oxide, probably because of oxidation during sample preparation. For $\mathbf{8 a}, \mathbf{b}$, the ions $\left[\mathrm{M}-2 \mathrm{X}^{-}\right]^{2+},\left[\mathrm{M}-3 \mathrm{X}^{-}\right]^{3+}$, and $\left[\mathrm{M}-4 \mathrm{X}^{-}\right]^{4+}(\mathrm{X}=\mathrm{I}(\mathbf{8 a}), \mathrm{Br}$ (8b)) were observed. For $\mathbf{8 c}, \mathbf{d}$, the $\left[\mathrm{M}-3 \mathrm{Br}^{-}\right]^{3+}$ and $\left[\mathrm{M}-4 \mathrm{Br}^{-}\right]^{4+}$ species were identified.

Furthermore, these triaryl phosphine derivatives were characterized by ${ }^{1} \mathrm{H},{ }^{13} \mathrm{C}$, and ${ }^{31} \mathrm{P}$ NMR spectrometry. To compare the ${ }^{31} \mathrm{P}$ shifts of the series of phosphine sulfides ( 4 and hexacationic $\mathbf{6 a}-\mathbf{c}$ ) and of the series of free phosphines (2, and hexacationic $\mathbf{8 a}-\mathbf{c})$ the NMR spectra were all measured in $\mathrm{CD}_{3} \mathrm{OD}$ (Table 1). Regrettably, the dendritic salts $6 \mathbf{d}$ and $\mathbf{8 d}$ are too insoluble to be measured in this solvent. Based on these shifts, a clear effect of charge introduction is observed. Upon quaternization of the amines in 4 an upfield shift of $-2.7 \mathrm{ppm}$ is observed for the phosphine sulfides $(\mathbf{6 a}-\mathbf{c})$. The fact that a similar upfield shift is found for the $\mathrm{HCl}$ salt of 4 ( $\delta=40.82 \mathrm{ppm})$, and a downfield shift of $+3.4 \mathrm{ppm}$ is found for the free phosphines $(\mathbf{8 a}-\mathbf{c})$, indicates that this could be caused by Coulombic repulsion between the ammonium groups. Most probably, such repulsion would lead to opening of the $\mathrm{C}-\mathrm{P}-\mathrm{C}$ angles. Opening of $\mathrm{C}-\mathrm{P}-\mathrm{C}$ angles in free triarylphosphines resulting from steric effects is known to lead to a downfield shift in ${ }^{31} \mathrm{P}$ NMR, due to a rehybridization at phosphorus. This results in an overall increase of electron density at the phosphorus atom. ${ }^{20}$ Because of the polarized $\mathrm{P}-\mathrm{S}$ bond in phosphine sulfides a similar rehybridization would result in a decrease in $\mathrm{P}-\mathrm{S}$ bond order, resulting in an overall decrease of electron density at phosphorus. Our current observations appear to be in agreement with this explanation. 

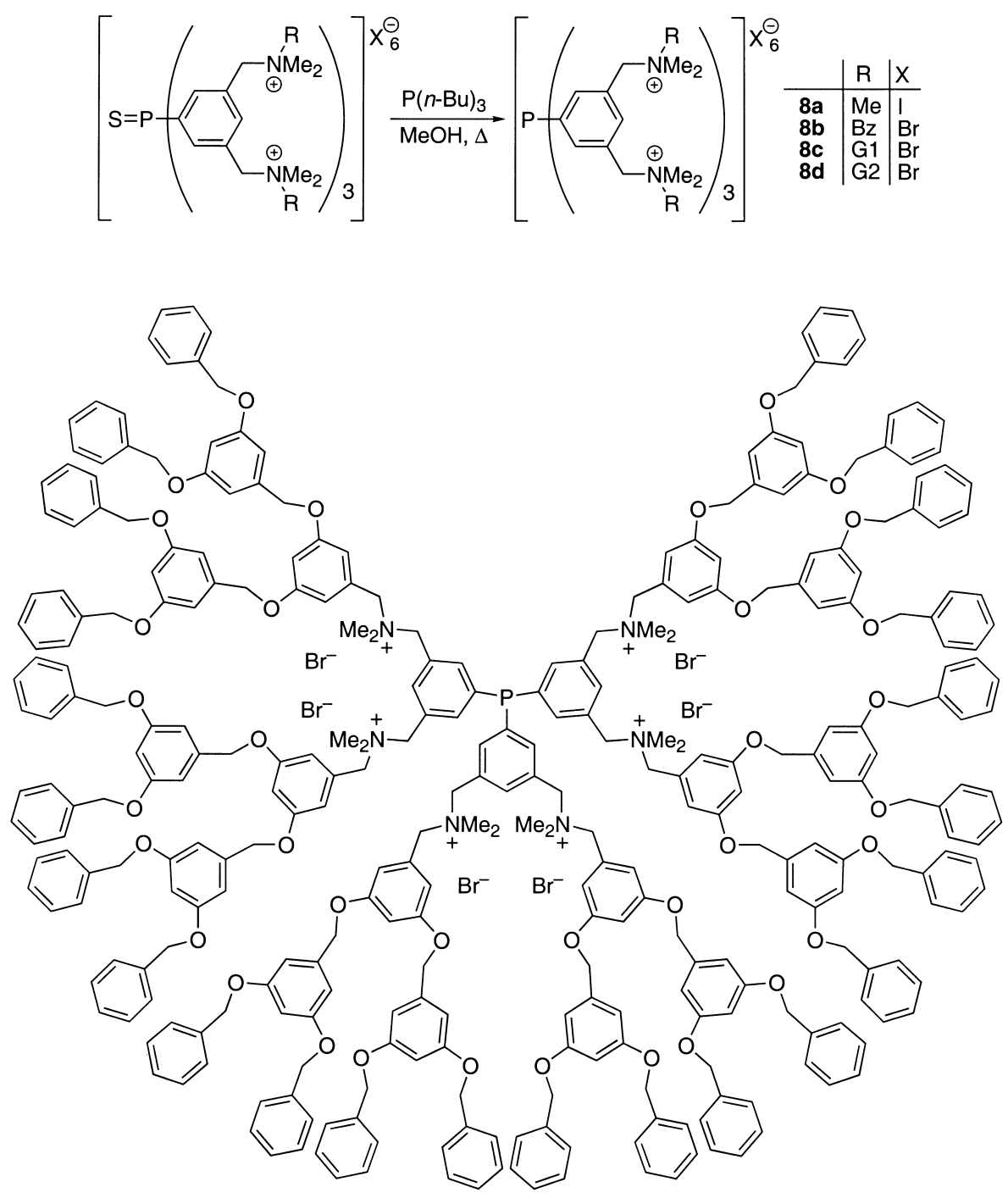

Scheme 3. Reduction of the phosphine sulfides $\mathbf{6 a - d}$ to afford the hexacationic triphenylphosphine analogues $\mathbf{8 a - d , ~ a n d ~ s t r u c t u r e ~ o f ~ D e n d r i p h o s ~} \mathbf{8 d}$.

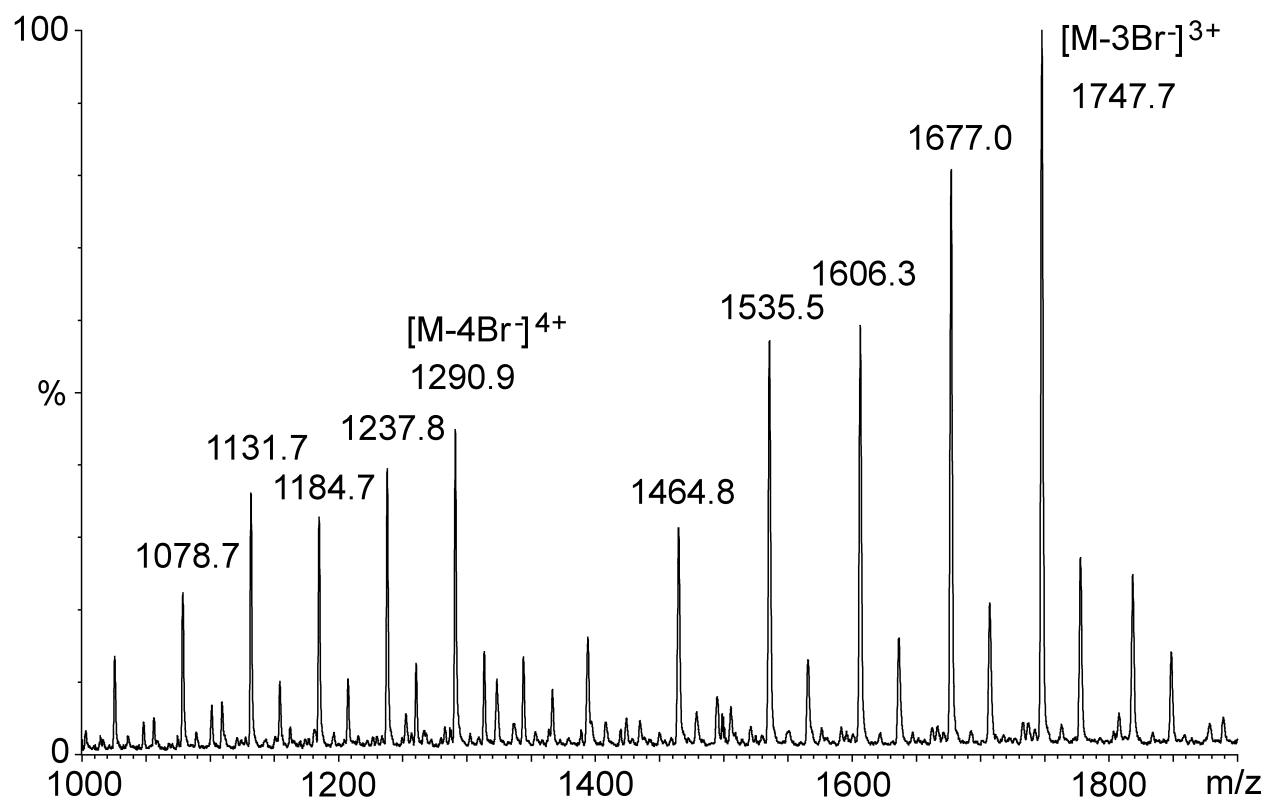

Figure 2. Representative mass spectrum of $6 \mathbf{d}$ showing characteristic peaks at $m / z=1747.7\left[\mathrm{M}^{-3} 3 \mathrm{Br}^{-}\right]^{3+}$, and $1290.0\left[\mathrm{M}^{-4} \mathrm{Br}^{-}\right]^{4+}$. 
Table 1. ${ }^{31} \mathrm{P}$ NMR data for the series of phosphine sulfides $\mathbf{4}$ and $\mathbf{6 a}-\mathbf{d}$, and free phosphines $\mathbf{2}$ and $\mathbf{8 a}-\mathbf{d}$ in $\mathrm{CD}_{3} \mathrm{OD}$

\begin{tabular}{|c|c|c|c|}
\hline$\left[\mathrm{S}=\mathrm{P}(\mathrm{NCN})_{3} \cdot \mathrm{R}_{6}\right] \mathrm{X}_{6}, \mathrm{RX}$ & ${ }^{31} \mathrm{P}$ NMR $\delta(\mathrm{ppm})$ & {$\left[\mathrm{P}(\mathrm{NCN})_{3} \cdot \mathrm{R}_{6}\right] \mathrm{X}_{6}, \mathrm{RX}$} & ${ }^{31} \mathrm{P}$ NMR $\delta(\mathrm{ppm})$ \\
\hline$-(4)$ & 43.40 & $-(2)$ & -5.30 \\
\hline MeI (6a) & 40.70 & $\operatorname{MeI}(\mathbf{8 a})$ & -1.90 \\
\hline $\mathrm{BzBr}(\mathbf{6 b})$ & 40.68 & $\mathrm{BzBr}(\mathbf{8 b})$ & -1.82 \\
\hline $\mathrm{G} 1 \mathrm{Br}(\mathbf{6 c})$ & 40.58 & $\mathrm{G} 1 \mathrm{Br}(\mathbf{8 c})$ & -1.68 \\
\hline $\mathrm{G} 2 \mathrm{Br}(\mathbf{6 d})$ & Insol & $\mathrm{G} 2 \mathrm{Br}(\mathbf{8 d})$ & Insol. \\
\hline
\end{tabular}

Enlargement of the $N$-substituents in the two series of ammonium salts seems to enlarge these effects, but only to a minor extent.

To obtain further information about the electronic effects on phosphorus, IR spectra of the phosphine oxides and sulfides were recorded. Unfortunately, the $\mathrm{P}=\mathrm{O}$ vibrations could not be distinguished from the aromatic and benzyl-phenyl ether vibrations. The $\mathrm{P}=\mathrm{S}$ vibrations are expected around $802-660$ and $730-550 \mathrm{~cm}^{-1} .^{21}$ In the spectrum of $\mathrm{S}=\mathrm{P}(\mathrm{NCN})_{3} 4$, sharp bands are observed that can be assigned to these vibrations (708 and $\left.558 \mathrm{~cm}^{-1}\right)$. Unfortunately, in the spectra of $\mathbf{6 a - d}$ these bands are obscured by the presence of many other vibrations and cannot be observed.

To gain insight in the size, cone angle, and threedimensional structure of these novel hexa-ammonium salts, we attempted to use X-ray diffraction. Although recrystallization of $\mathrm{O}=\mathrm{P}(\mathrm{NCN})_{3}(3)$ from hexane yielded analytically pure crystals, diffraction patterns could not be observed as these crystals underwent a solid-solid phase change upon cooling. Furthermore, when measured at $-60^{\circ} \mathrm{C}$, just above the phase change, included hexane slowly started to evaporate from the crystals leading to disruption of the 3-D structure. For this reason we turned to molecular modeling to obtain information on the structural features of the Dendriphos compounds in particular. Because of the presence of meta-substituents in these triarylphosphines, hindered rotation of the aryl rings around the $\mathrm{P}-\mathrm{C}$ (aryl) bond would be expected. This is reflected in their ${ }^{1} \mathrm{H},{ }^{13} \mathrm{C}$, and ${ }^{31} \mathrm{P}$ NMR spectra, which become increasingly broad going from $\mathbf{4}$ to $\mathbf{6 d}$ and from $\mathbf{2}$ to $\mathbf{8 d}$. To investigate this, NMR spectra of $\mathbf{8 d}$ were recorded at elevated temperatures. Upon heating, the signals of the $\mathrm{NMe}_{2}$ and $\left(\mathrm{NMe}_{2}\right) \mathrm{CH}_{2}$ protons narrow, while the signals corresponding to the dendron-aryl protons remain broad. Furthermore, decoalescence of the signals corresponding to

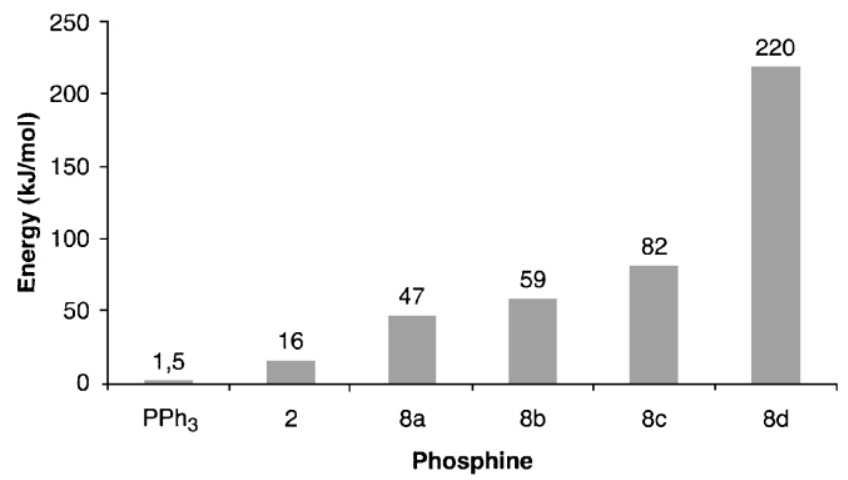

Figure 3. Energy plot of the rotation barrier of the aryl rings around the $\mathrm{P}-\mathrm{C}$ (aryl) bond in triarylphosphines against the type of meta-substituent. the core aryl-protons occurs, and two separate signals can be observed. A detailed study on the NMR behavior of these phosphines at variable temperatures is currently being carried out and will reported elsewhere. In parallel, calculations on the rotation of aryl fragments around the phosphine-aryl bond were performed for the series of phosphines $\mathbf{2}$ and $\mathbf{8 a}-\mathbf{d}$. These calculations show that the rotation barriers increase with increasing size of the $N$-substituent (Fig. 3). Whereas the parent triarylphosphine, 2 has a rotation barrier of $16 \mathrm{~kJ} / \mathrm{mol}$ (compare this to the calculated barrier for triphenylphosphine: $1.5 \mathrm{~kJ} / \mathrm{mol}$ ), Dendriphos 8c,d have rotation barriers increasing to 82 (G1) and $220 \mathrm{~kJ} / \mathrm{mol}$ (G2). These gas-phase MM2 calculations also showed that the rotations of the aryl fragments are correlated. Moreover, it was observed that the counterions stay in close proximity to the cations, and rotate with the aryl fragments. From these calculated rotational barriers can be concluded that for the Dendriphos compounds, rotation around the phosphorus-aryl bond is virtually impossible under ambient conditions.

Molecular modeling was further applied to study the threedimensional structure of the hexacationic phosphines. These studies showed that the phosphorus atom becomes increasingly buried in the organic bulk with increasing size of the $\mathrm{N}$-substituents. For the Dendriphos compounds 8c,d this results in disc-like rather than cone-like structures. In the case of $\left[\mathrm{P}(\mathrm{NCN})_{3} \cdot(\mathrm{G} 2)_{6}\right] \mathrm{Br}_{6}(\mathbf{8 d})$, a nanosize disc is obtained with a diameter of $3.5 \mathrm{~nm}$ and a height of approximately $2.0 \mathrm{~nm}^{\dagger}$ (Fig. 4). These discs consist of a rigid triarylphosphine core, surrounded by a ring of ionic groups. The ammonium groups are shielded by a soft shell of dendrons with increased peripheral conformational freedom. Based on our calculations, a cone angle ${ }^{20}$ of $180^{\circ}$ could be tentatively assigned to this macromolecular phosphine.

\section{Conclusions}

In summary, a new bifunctional hexa-amine triarylphosphine core molecule was prepared and converted to the corresponding phosphine oxide and phosphine sulfide. The resulting protected phosphines were used as core molecules for the synthesis of hexa-ammonium salts via alkylation of the amine functionalities. The hexacationic phosphine sulfides could be reduced to the free phosphines via a general method. In this way, a series of hexacationic phosphines has become available, starting from relatively straightforward building blocks, and following an easy protection, alkylation, deprotection reaction sequence. The

\footnotetext{
$\bar{\dagger}$ Obtained by taking the mean value of several distance measurements in the structure.
} 

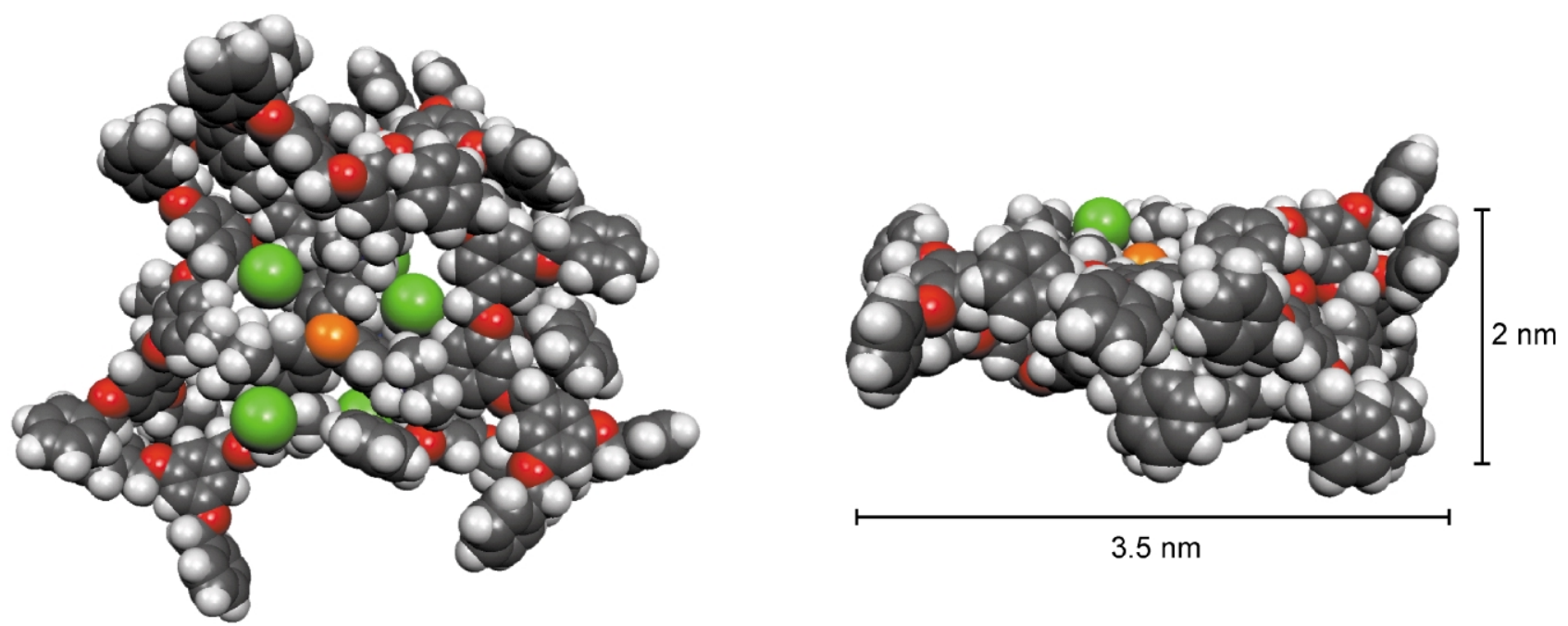

Figure 4. Top and side view of $\left[\mathrm{P}(\mathrm{NCN})_{3}(\mathrm{G} 2)_{6}\right] \mathrm{Br}_{6}(\mathbf{8 d})$, showing the disc-like character and dimensions of this Dendriphos. The $\mathrm{P}$-atom is shown in orange, the $\mathrm{Br}^{-}$counterions are shown in green. Three of the $\mathrm{Br}^{-}$ions are found on top of and three below the disc.

solubility of these hexacations dramatically changes by varying the $N$-substituent, which hints at the application of these compounds in both aqueous and non-aqueous media. ${ }^{22}$ From ${ }^{31} \mathrm{P}$ NMR data it can be concluded that the $\mathrm{C}-\mathrm{P}-\mathrm{C}$ angles of these meta-substituted Dendriphos ligands increase with increasing size of the (meta-) $N$-substituent, opening the way for tuning the properties of metal complexes derived from these ligands by means of variation of this substituent. The position and size of the counterions in such complexes could be of additional importance to the final $\mathrm{C}-\mathrm{P}-\mathrm{C}$ angle and to the effective cone angle of these hexacationic ligands. Both the physical properties as well as the coordination behaviour of this series of phosphines are the subject of current investigations.

\section{Experimental}

\subsection{General}

All lithiation reactions and manipulations of the phosphines were performed using standard Schlenk techniques. $\mathrm{Et}_{2} \mathrm{O}$ was dried over $\mathrm{Na}$ /benzophenone and distilled prior to use. 1-Bromo-3,5-bis[(dimethylamino)methyl]benzene, $\mathbf{1}^{17}$ and the benzylic bromides of the Fréchet dendrons (G1 and G2) ${ }^{18}$ were prepared according to literature procedures. $\mathrm{PBr}_{3}$ was distilled prior to use. All other starting materials were obtained from Acros Chimica or Sigma-Aldrich and were used without further purification. ${ }^{1} \mathrm{H},{ }^{13} \mathrm{C}\left\{{ }^{1} \mathrm{H}\right\}$, and ${ }^{31} \mathrm{P}\left\{{ }^{1} \mathrm{H}\right\}$ NMR measurements were carried out on a Varian Inova $200 \mathrm{MHz}$ spectrometer at $25^{\circ} \mathrm{C}$ and all chemical shifts $(\delta)$ are given in ppm. The ${ }^{1} \mathrm{H}$ NMR spectra were referenced against the solvent residual peak and the ${ }^{31} \mathrm{P}$ NMR spectra against $85 \% \quad \mathrm{H}_{3} \mathrm{PO}_{4}$ as external standard. MALDI-TOF mass spectra were recorded on a Voyager-DE BioSpectrometry Workstation mass spectrometer. Nano-ESI mass spectra were recorded on a Micromass LC-TOF mass spectrometer. IR spectra were recorded on a PE-system 2000 FT-IR spectrometer. Elemental analyses were performed by Kolbe, Mülheim a/d Ruhr, Germany.
4.1.1. Synthesis of $\mathrm{O}=\mathbf{P}(\mathbf{N C N})_{3}$ (3). To a solution of 1-bromo-3,5-bis[(dimethylamino)methyl]benzene (Br-NCN, 1) $(4.84 \mathrm{~g}, 17.9 \mathrm{mmol})$ in $\mathrm{Et}_{2} \mathrm{O}, 2$ equiv. of $t$-BuLi (1.5 M in pentane, $23.8 \mathrm{~mL}, 35.7 \mathrm{mmol}$ ) were added dropwise under $\mathrm{N}_{2}$ at $-78^{\circ} \mathrm{C}$. The resulting light brown suspension was stirred for $1 \mathrm{~h}$, after which $\mathrm{PBr}_{3}(0.56 \mathrm{~mL}, 5.96 \mathrm{mmol})$ was added dropwise. The mixture was allowed to warm up to room temperature, and was stirred for $16 \mathrm{~h}$. Degassed $\mathrm{H}_{2} \mathrm{O}(100 \mathrm{~mL})$ was added and the organic layer was separated. The aqueous layer was extracted twice with $\mathrm{CH}_{2} \mathrm{Cl}_{2}(2 \times 75 \mathrm{~mL})$, the combined organic fractions were dried over $\mathrm{MgSO}_{4}$ and evaporated in vacuo, affording crude $\mathbf{2}$ as a yellow oil. To this oil, THF $(100 \mathrm{~mL})$ was added and the solution was cooled to $0^{\circ} \mathrm{C} . \mathrm{H}_{2} \mathrm{O}_{2}\left(35 \%\right.$ in $\left.\mathrm{H}_{2} \mathrm{O}, 5 \mathrm{~mL}\right)$ was added and the mixture was stirred in air for $3 \mathrm{~h}$. Aqueous $\mathrm{NaOH}(1 \mathrm{M}, 100 \mathrm{~mL})$ was added and the mixture was concentrated. The product was extracted with $\mathrm{CH}_{2} \mathrm{Cl}_{2}(2 \times 100 \mathrm{~mL})$, the combined organic layers were dried over $\mathrm{MgSO}_{4}$, and evaporated to dryness. The crude product was further purified by crystallization from hexane and obtained as colorless crystals $(1.21 \mathrm{~g}, 33 \%) .{ }^{1} \mathrm{H}$ NMR $\left(200 \mathrm{MHz}, \mathrm{CDCl}_{3}\right.$ ): $\delta=7.49,7.43$ (overlapping s and d, $9 \mathrm{H}$, $\mathrm{Ar}-\mathrm{H}), 3.37$ (s, 12H, Ar- $\left.\mathrm{CH}_{2}\right), 2.15\left(\mathrm{~s}, 36 \mathrm{H}, \mathrm{N}\left(\mathrm{CH}_{3}\right)_{2}\right) ;{ }^{13} \mathrm{C}$ $\left\{{ }^{1} \mathrm{H}\right\} \mathrm{NMR}\left(50 \mathrm{MHz}, \mathrm{CDCl}_{3}\right): \delta=139.61 \quad(\mathrm{~d}, \mathrm{Ar}-\mathrm{C}$, ${ }^{2} J_{\mathrm{CP}}=12.0 \mathrm{~Hz}$ ), 133.62 (s, Ar-C), 133.49 (s, Ar-C), 131.67 (d, $\left.\mathrm{Ar}-\mathrm{C},{ }^{3} \mathrm{~J}_{\mathrm{CP}}=10.1 \mathrm{~Hz}\right), 64.00\left(\mathrm{~s}, \mathrm{ArCH}_{2}\right), 45.48(\mathrm{~s}$, $\left.\mathrm{N}\left(\mathrm{CH}_{3}\right)_{2}\right) ;{ }^{31} \mathrm{P}\left\{{ }^{1} \mathrm{H}\right\} \mathrm{NMR}\left(81 \mathrm{MHz}, \mathrm{CDCl}_{3}\right): \delta=30.13$ (s); MALDI-TOF MS: $\mathrm{m} / z 620.39 \mathrm{M}^{+}(100 \%)$. Anal. calcd for $\mathrm{C}_{36} \mathrm{H}_{57} \mathrm{~N}_{6} \mathrm{OP}: \mathrm{C}$ 69.64, H 9.25, N 13.54, P 4.99. Found: $\mathrm{C}$ 69.64, H 9.21, N 13.40, P 4.91.

4.1.2. Synthesis of $\mathbf{S}=\mathbf{P}(\mathbf{N C N})_{3}$ (4). $S=P(N C N)_{3}$ was prepared similarly to the synthesis described above for $\mathrm{O}=\mathrm{P}(\mathrm{NCN})_{3}$, starting from $\mathrm{Br}-\mathrm{NCN} \quad$ (1) (4.54 g, $16.75 \mathrm{mmol})$ and $\mathrm{PBr}_{3}(0.44 \mathrm{~mL}, 4.68 \mathrm{mmol})$. To the resulting crude $\mathrm{P}(\mathrm{NCN})_{3}(2)$, sulfur $(0.54 \mathrm{~g}, 16.84 \mathrm{mmol})$ dissolved in $\mathrm{CS}_{2}(50 \mathrm{~mL})$ was added in one portion. The mixture was stirred for $16 \mathrm{~h}$ and evaporated to dryness, yielding a yellow sticky solid. The crude mixture was purified by addition of $\mathrm{HCl}(1 \mathrm{M}, 100 \mathrm{~mL})$ followed by washing with $\mathrm{CH}_{2} \mathrm{Cl}_{2}$, and addition of $\mathrm{NaOH}(4 \mathrm{M}, 150 \mathrm{~mL})$ followed by extraction of the product with $\mathrm{CH}_{2} \mathrm{Cl}_{2}$ 
$(2 \times 100 \mathrm{~mL})$. The product containing organic fractions were combined, dried over $\mathrm{MgSO}_{4}$, and evaporated to dryness. The obtained sticky material was washed twice with cold pentane to afford a light yellow solid $(2.98 \mathrm{~g}, 84 \%) .{ }^{1} \mathrm{H}$ NMR $\left(200 \mathrm{MHz}, \mathrm{CDCl}_{3}\right): \delta=7.51,7.44$ (overlapping $\mathrm{s}$ and $\mathrm{d}, 9 \mathrm{H}, \mathrm{Ar}-\mathrm{H}), 3.36\left(\mathrm{~s}, 12 \mathrm{H}, \mathrm{Ar}-\mathrm{CH}_{2}\right), 2.16(\mathrm{~s}, 36 \mathrm{H}$, $\left.\mathrm{N}\left(\mathrm{CH}_{3}\right)_{2}\right) ;{ }^{13} \mathrm{C}\left\{{ }^{1} \mathrm{H}\right\} \mathrm{NMR}\left(50 \mathrm{MHz}, \mathrm{CDCl}_{3}\right): \delta=139.55(\mathrm{~d}$, $\left.\mathrm{Ar}-\mathrm{C},{ }^{2} J_{\mathrm{CP}}=12.4 \mathrm{~Hz}\right), 133.17(\mathrm{~s}, \mathrm{Ar}-\mathrm{C}), 131.68$ (d, Ar-C, $\left.{ }^{1} J_{\mathrm{C}-\mathrm{P}}=84.3 \mathrm{~Hz}\right), 131.81\left(\mathrm{~d}, \mathrm{Ar}-\mathrm{C},{ }^{3} J_{\mathrm{CP}}=11.1 \mathrm{~Hz}\right), 64.00$ $\left(\mathrm{s}, \mathrm{ArCH} \mathrm{H}_{2}\right), 45.49$ (s, N( $\left.\left.\mathrm{CH}_{3}\right)_{2}\right) ;{ }^{31} \mathrm{P}\left\{{ }^{1} \mathrm{H}\right\} \mathrm{NMR}(81 \mathrm{MHz}$, $\left.\mathrm{CDCl}_{3}\right): \delta=43.40$ (s); MALDI-TOF MS: $m / z 637.09 \mathrm{M}^{+}$ (100\%). Anal. calcd for $\mathrm{C}_{36} \mathrm{H}_{57} \mathrm{~N}_{6} \mathrm{PS}$ : C 67.89, H 9.02, N 13.19, P 4.86. Found: C 67.86, H 8.95, N 13.08, P 4.99.

4.1.3. Synthesis of $\left[\mathrm{O}=\mathbf{P}(\mathbf{N C N})_{3} \cdot \mathbf{M e}_{6}\right] \mathbf{I}_{6} \quad(5 a)$. To a solution of $\mathrm{O}=\mathrm{P}(\mathrm{NCN})_{3}(\mathbf{3}, 0.33 \mathrm{~g}, 0.53 \mathrm{mmol})$ in $\mathrm{CH}_{2} \mathrm{Cl}_{2}$ $(50 \mathrm{~mL})$ was added MeI $(0.40 \mathrm{~mL}, 6.42 \mathrm{mmol})$ and the mixture was stirred for $4 \mathrm{~h}$, during which the product precipitated. The solid material was collected and washed with $\mathrm{CH}_{2} \mathrm{Cl}_{2}(2 \mathrm{x} 30 \mathrm{~mL})$, and further purified by precipitation from $\mathrm{MeOH}(10 \mathrm{~mL})$ with $\mathrm{Et}_{2} \mathrm{O}(75 \mathrm{~mL})$, affording a light yellow solid $(0.54 \mathrm{~g}, 68 \%)$. ${ }^{1} \mathrm{H}$ NMR $\left(200 \mathrm{MHz}, \mathrm{D}_{2} \mathrm{O}\right): \delta=8.69\left(\mathrm{~d}, 6 \mathrm{H}, \mathrm{Ar}-\mathrm{H},{ }^{2} J_{\mathrm{HP}}=12.6 \mathrm{~Hz}\right)$, 8.13 (s, 3H, Ar-H), 4.74 (s, $\left.12 \mathrm{H}, \mathrm{Ar}-\mathrm{CH}_{2}\right), 3.24(\mathrm{~s}, 48 \mathrm{H}$, $\mathrm{N}\left(\mathrm{CH}_{3}\right)_{3} ;{ }^{13} \mathrm{C}\left\{{ }^{1} \mathrm{H}\right\} \mathrm{NMR}\left(50 \mathrm{MHz}, \mathrm{D}_{2} \mathrm{O}\right): \delta=142.71(\mathrm{~s}$, $\mathrm{Ar}-\mathrm{C}), 138.68\left(\mathrm{~d}, \mathrm{Ar}-\mathrm{C},{ }^{3} J_{\mathrm{CP}}=10.6 \mathrm{~Hz}\right), 132.17(\mathrm{~d}, \mathrm{Ar}-\mathrm{C}$, $\left.{ }^{1} J_{\mathrm{C}-\mathrm{P}}=107.3 \mathrm{~Hz}\right), 130.55\left(\mathrm{~d}, \mathrm{Ar}-\mathrm{C},{ }^{2} J_{\mathrm{CP}}=12.9 \mathrm{~Hz}\right), 67.71$ $\left(\mathrm{s}, \mathrm{ArCH} \mathrm{H}_{2}\right), 53.30\left(\mathrm{~s}, \mathrm{~N}\left(\mathrm{CH}_{3}\right)_{3}\right) ;{ }^{31} \mathrm{P}\left\{{ }^{1} \mathrm{H}\right\} \mathrm{NMR}(81 \mathrm{MHz}$, $\left.\mathrm{D}_{2} \mathrm{O}\right): \delta=32.93(\mathrm{~s})$; nano-ESI MS: $m / z, 1345.58\left[\mathrm{M}-\mathrm{I}^{-}\right]^{+}$ $(1 \%), 609.11\left[\mathrm{M}-2 \mathrm{I}^{-}\right]^{2+}(28 \%), 363.79\left[\mathrm{M}-3 \mathrm{I}^{-}\right]^{3+}(82 \%)$, $241.24\left[\mathrm{M}-4 \mathrm{I}^{-}\right]^{4+}(100 \%), 167.76\left[\mathrm{M}-5 \mathrm{I}^{-}\right]^{5+}(46 \%)$, $118.81\left[\mathrm{M}-6 \mathrm{I}^{-}\right]^{6+}(7 \%)$. Anal. calcd for $\mathrm{C}_{42} \mathrm{H}_{75} \mathrm{I}_{6} \mathrm{~N}_{6} \mathrm{OP}: \mathrm{C}$ 34.26, H 5.13, N 5.71, P, 2.10. Found: C 34.21, H 5.20, N 5.64, P 1.97 .

4.1.4. Synthesis of $\left[S=P(N C N)_{3} \cdot M^{-} e_{6}\right] I_{6}$ (6a). Similar to the procedure described for $\mathbf{5 a}$, starting from $\mathrm{S}=\mathrm{P}(\mathrm{NCN})_{3}$ $(4,0.20 \mathrm{~g}, 0.31 \mathrm{mmol})$ and $\mathrm{MeI}(0.20 \mathrm{~mL}, 3.21 \mathrm{mmol}), \mathbf{6 a}$ was obtained as a light yellow solid $(0.36 \mathrm{~g}, 76 \%) .{ }^{1} \mathrm{H}$ NMR $\left(200 \mathrm{MHz}, \mathrm{D}_{2} \mathrm{O}\right): \delta=8.51\left(\mathrm{~d}, 6 \mathrm{H}, \mathrm{Ar}-\mathrm{H},{ }^{2} J_{\mathrm{HP}}=13.6 \mathrm{~Hz}\right)$, 8.08 (s, 3H, Ar-H), 4.75 (s, $\left.12 \mathrm{H}, \mathrm{ArCH}_{2}\right), 3.25$ (s, 48H, $\left.\mathrm{N}\left(\mathrm{CH}_{3}\right)_{3}\right) ;{ }^{13} \mathrm{C}\left\{{ }^{1} \mathrm{H}\right\}$ NMR $\left(50 \mathrm{MHz}, \mathrm{D}_{2} \mathrm{O}\right): \delta=142.77(\mathrm{~s}$, $\mathrm{Ar}-\mathrm{C}), 138.70\left(\mathrm{~d}, \mathrm{Ar}-\mathrm{C},{ }^{3} J_{\mathrm{CP}}=11.0 \mathrm{~Hz}\right), 132.17(\mathrm{~d}, \mathrm{Ar}-\mathrm{C}$, $\left.{ }^{1} J_{\mathrm{C}-\mathrm{P}}=107.3 \mathrm{~Hz}\right), 130.55\left(\mathrm{~d}, \mathrm{Ar}-\mathrm{C},{ }^{2} J_{\mathrm{CP}}=13.4 \mathrm{~Hz}\right), 67.69$ $\left(\mathrm{s}, \mathrm{ArCH} \mathrm{H}_{2}\right), 53.30\left(\mathrm{~s}, \mathrm{~N}\left(\mathrm{CH}_{3}\right)_{3}\right) ;{ }^{31} \mathrm{P}\left\{{ }^{1} \mathrm{H}\right\} \mathrm{NMR}(81 \mathrm{MHz}$, $\left.\mathrm{D}_{2} \mathrm{O}\right): \delta=44.29(\mathrm{~s})$; nano-ESI MS: $m / z 1361.64\left[\mathrm{M}-\mathrm{I}^{-}\right]^{+}$ $(1 \%), 617.17\left[\mathrm{M}-2 \mathrm{I}^{-}\right]^{2+}(21 \%), \quad 368.63\left[\mathrm{M}-3 \mathrm{I}^{-}\right]^{3+}$ $(100 \%), 244.22\left[\mathrm{M}-4 \mathrm{I}^{-}\right]^{4+}(32 \%)$. Anal. calcd for $\mathrm{C}_{42} \mathrm{H}_{75} \mathrm{I}_{6} \mathrm{~N}_{6} \mathrm{PS}$ : C 33.89, H 5.08, N 5.65, P 2.08. Found: C 34.08, H 5.20, N 5.57, P 2.07.

4.1.5. Synthesis of $\left[\mathrm{O}=\mathbf{P}(\mathrm{NCN})_{3} \cdot \mathrm{Bz}_{6}\right] \mathrm{Br}_{6}$ (5b). To a solution of $\mathrm{O}=\mathrm{P}(\mathrm{NCN})_{3}(3,1.11 \mathrm{~g}, 1.79 \mathrm{mmol})$ in $\mathrm{CH}_{2} \mathrm{Cl}_{2}$ was added benzyl bromide $(1.4 \mathrm{~mL}, 11.71 \mathrm{mmol})$ and the mixture was stirred for $16 \mathrm{~h}$. The yellow suspension was evaporated to dryness and the resulting solid was precipitated twice from $\mathrm{MeOH}(10 \mathrm{~mL})$ using $\mathrm{Et}_{2} \mathrm{O}(75 \mathrm{~mL})$, affording a light yellow solid $(2.13 \mathrm{~g}, 72 \%)$. ${ }^{1} \mathrm{H}$ NMR $\left(200 \mathrm{MHz}, \mathrm{CD}_{3} \mathrm{OD}\right): \delta=8.69$ (d, $\left.6 \mathrm{H}, \mathrm{Ar}-\mathrm{H},{ }^{3} J_{\mathrm{HP}}=12.6 \mathrm{~Hz}\right)$, 8.21 (s, 3H, Ar-H), 7.8-7.4 (m, 30H, $\left.\mathrm{CH}_{2} \mathrm{Ar}-H\right), 4.85$ (s, $\left.12 \mathrm{H}, \mathrm{ArCH}_{2}\right), 4.74\left(\mathrm{~s}, 12 \mathrm{H}, \mathrm{ArCH}_{2}\right), 3.10(\mathrm{~s}, 36 \mathrm{H}$, $\left.\mathrm{N}\left(\mathrm{CH}_{3}\right)_{2}\right) ;{ }^{13} \mathrm{C}\left\{{ }^{1} \mathrm{H}\right\} \mathrm{NMR}\left(50 \mathrm{MHz}, \mathrm{CD}_{3} \mathrm{OD}\right): \delta=142.38$ $(\mathrm{s}, \mathrm{Ar}-\mathrm{C}), 139.24\left(\mathrm{~d}, \mathrm{Ar}-\mathrm{C},{ }^{3} J_{\mathrm{CP}}=11.0 \mathrm{~Hz}\right), 133.75$ (d,
$\left.\mathrm{Ar}-\mathrm{C},{ }^{1} J_{\mathrm{CP}}=105.30 \mathrm{~Hz}\right), 133.48(\mathrm{~s}, \mathrm{Ar}-\mathrm{C}), 130.78(\mathrm{~s}$, $\mathrm{Ar}-\mathrm{C}), 130.39$ (d, Ar-C, $\left.{ }^{2} J_{\mathrm{CP}}=13.3 \mathrm{~Hz}\right) 129.11(\mathrm{~s}, \mathrm{Ar}-\mathrm{C})$, $127.62(\mathrm{~s}, \mathrm{Ar}-\mathrm{C}), 67.17\left(\mathrm{~s}, \mathrm{ArCH} \mathrm{H}_{2}\right), 48.72\left(\mathrm{~s}, \mathrm{~N}\left(\mathrm{CH}_{3}\right)_{2}\right) ;{ }^{31} \mathrm{P}$ $\left\{{ }^{1} \mathrm{H}\right\}$ NMR (81 MHz, CD $\left.3 \mathrm{OD}\right): \delta=32.93$ (s); nano-ESI MS: $m / z 743.25[\mathrm{M}-2 \mathrm{Br}]^{2+}(18 \%), 469.18\left[\mathrm{M}-3 \mathrm{Br}^{-}\right]^{3+}(92 \%)$, $331.72\left[\mathrm{M}-4 \mathrm{Br}^{-}\right]^{4+}(100 \%)$. Anal. calcd for $\mathrm{C}_{78} \mathrm{H}_{99} \mathrm{Br}_{6}{ }^{-}$ $\mathrm{N}_{6} \mathrm{OP}: \mathrm{C} 56.88, \mathrm{H}$ 6.06, N 5.10, P, 1.88. Found: C 57.02, H 6.12 , N 5.13, P 1.98 .

4.1.6. Synthesis of $\left[S=P(N C N)_{3} \cdot B_{6}\right] \mathbf{B r}_{6}(6 b)$. Similar to the procedure described for $\mathbf{5 b}$, starting from $\mathrm{S}=\mathrm{P}(\mathrm{NCN})_{3}$ $(4,0.25 \mathrm{~g}, 0.39 \mathrm{mmol})$ and benzyl bromide $(0.30 \mathrm{~mL}$, $2.51 \mathrm{mmol}), \mathbf{6 b}$ was obtained as a light yellow solid (0.61 g, 94\%). ${ }^{1} \mathrm{H}$ NMR (200 MHz, $\left.\mathrm{CD}_{3} \mathrm{OD}\right): \delta=8.79(\mathrm{~d}$, $\left.6 \mathrm{H}, \mathrm{Ar}-\mathrm{H},{ }^{3} J_{\mathrm{HP}}=13.6 \mathrm{~Hz}\right), 8.14(\mathrm{~s}, 3 \mathrm{H}, \mathrm{Ar}-\mathrm{H}), 7.8-7.4(\mathrm{~m}$, $\left.30 \mathrm{H}, \mathrm{CH}_{2} \mathrm{Ar}-\mathrm{H}\right), 4.86\left(\mathrm{~s}, 12 \mathrm{H}, \mathrm{ArCH}_{2}\right), 4.79(\mathrm{~s}, 12 \mathrm{H}$, $\left.\mathrm{ArCH}_{2}\right), 3.241\left(\mathrm{~s}, 36 \mathrm{H}, \mathrm{N}\left(\mathrm{CH}_{3}\right)_{2}\right) ;{ }^{13} \mathrm{C}\left\{{ }^{1} \mathrm{H}\right\} \mathrm{NMR}(50 \mathrm{MHz}$, $\left.\mathrm{CD}_{3} \mathrm{OD}\right): \delta=141.42(\mathrm{~s}, \mathrm{Ar}-\mathrm{C}), 139.308$ (d, Ar-C, ${ }^{3} J_{\mathrm{CP}}=11.9 \mathrm{~Hz}$ ), 136.32 (overlapping d, Ar-C), 133.47 (s, $\mathrm{Ar}-\mathrm{C}), 130.78(\mathrm{~s}, \mathrm{Ar}-\mathrm{C}), 130.10\left(\mathrm{~d}, \mathrm{Ar}-\mathrm{C},{ }^{2} J_{\mathrm{CP}}=13.3 \mathrm{~Hz}\right)$, 129.11 (s, $\mathrm{Ar}-\mathrm{C}), 127.62(\mathrm{~s}, \mathrm{Ar}-\mathrm{C}), 67.16\left(\mathrm{~s}, \mathrm{ArCH}_{2}\right)$, $48.70\left(\mathrm{~s}, \mathrm{~N}\left(\mathrm{CH}_{3}\right)_{2}\right) ;{ }^{31} \mathrm{P}\left\{{ }^{1} \mathrm{H}\right\}$ NMR $\left(81 \mathrm{MHz}, \mathrm{CD}_{3} \mathrm{OD}\right)$ : $\delta=40.68(\mathrm{~s})$; nano-ESI MS: $m / z 751.24[\mathrm{M}-2 \mathrm{Br}]^{2+}(28 \%)$, $447.50\left[\mathrm{M}-3 \mathrm{Br}^{-}\right]^{3+}(100 \%), 335.70\left[\mathrm{M}-4 \mathrm{Br}^{-}\right]^{4+}(71 \%)$. Anal. calcd for $\mathrm{C}_{78} \mathrm{H}_{99} \mathrm{Br}_{6} \mathrm{~N}_{6} \mathrm{PS}$ : C 34.26, H 5.13, N 5.71, P, 2.10. Found: C 34.21, H 5.20, N 5.64, P1.97.

4.1.7. Synthesis of $\left[\mathrm{O}=\mathbf{P}(\mathrm{NCN})_{3} \cdot(\mathrm{G1})_{6}\right] \mathrm{Br}_{6}(5 \mathrm{c})$. To a solution of $\mathrm{O}=\mathrm{P}(\mathrm{NCN})_{3}(3,0.55 \mathrm{~g}, 0.89 \mathrm{mmol})$ in $\mathrm{CH}_{2} \mathrm{Cl}_{2}$ $(100 \mathrm{~mL})$ was added $\mathrm{G} 1 \mathrm{Br}(2.04 \mathrm{~g}, 5.32 \mathrm{mmol})$ in one portion after which the mixture was stirred at room temperature for $16 \mathrm{~h}$. The resulting solution was concentrated and the product was precipitated with $\mathrm{Et}_{2} \mathrm{O}(75 \mathrm{~mL})$. The crude product was further purified by precipitating three times from $\mathrm{CH}_{2} \mathrm{Cl}_{2}(20 \mathrm{~mL})$ with $\mathrm{Et}_{2} \mathrm{O}(75 \mathrm{~mL})$ affording $\mathbf{5 c}$ as a white solid $(1.95 \mathrm{~g}, 75 \%)$. ${ }^{1} \mathrm{H} \mathrm{NMR}\left(200 \mathrm{MHz}, \mathrm{CDCl}_{3}\right)$ : $\delta=8.81$ (broad, 9H, overlapping $\mathrm{ArH}), 7.8-7.0(\mathrm{~m}, 60 \mathrm{H}$, ArH), 6.94 (broad s, 16H, ArH), 6.60 (broad s, 8H, ArH), 5.4-4.5 (broad, 48H, overlapping $\mathrm{ArCH}_{2}$ ), 3.05 (broad s, $\left.36 \mathrm{H}, \quad \mathrm{N}\left(\mathrm{CH}_{3}\right)_{2}\right) ;{ }^{13} \mathrm{C} \quad\left\{{ }^{1} \mathrm{H}\right\} \quad \mathrm{NMR} \quad\left(50 \mathrm{MHz}, \mathrm{CDCl}_{3}\right)$ : $\delta=160.13,142.88,139.46,136.50,133.66(\mathrm{Ar}-\mathrm{C}) 130.20$ $\left(\mathrm{d}, \mathrm{Ar}-\mathrm{C},{ }^{2} J_{\mathrm{CP}}=13.3 \mathrm{~Hz}\right.$ ), 130.05-127.97 (m, overlapping $\mathrm{Ar}-\mathrm{C}), \quad 112.69,104.71(\mathrm{Ar}-\mathrm{C}) 70.48\left(\mathrm{OCH}_{2}\right), 66.98$ (broad, $\left.\mathrm{CH}_{2} \mathrm{NCH}_{2}\right) \quad 49.36\left(\mathrm{~N}\left(\mathrm{CH}_{3}\right)_{2}\right) ;{ }^{31} \mathrm{P}\left\{{ }^{1} \mathrm{H}\right\} \quad \mathrm{NMR}$ $\left(81 \mathrm{MHz}, \mathrm{CDCl}_{3}\right): \delta=26.01$ (broad s); nano-ESI MS: $\mathrm{m} / \mathrm{z}$ $1380.63[\mathrm{M}-2 \mathrm{Br}]^{2+}(3 \%), 893.46\left[\mathrm{M}-3 \mathrm{Br}^{-}\right]^{3+}(40 \%)$, $650.36\left[\mathrm{M}-4 \mathrm{Br}^{-}\right]^{4+}(100 \%)$. Anal. calcd for $\mathrm{C}_{162} \mathrm{H}_{171} \mathrm{Br}_{6^{-}}$ $\mathrm{N}_{6} \mathrm{O}_{13} \mathrm{P}: \mathrm{C}$ 66.62, H 5.90, N 2.88, P 1.06. Found: C 66.48, H6.03, N 2.96, P 1.13.

4.1.8. Synthesis of $\left[S=P(N C N)_{3} \cdot(G 1)_{6}\right] B r_{6}(6 c)$. Similar to the procedure described for $\mathbf{5 c}$, starting from $\mathrm{S}=\mathrm{P}(\mathrm{NCN})_{3}$ $(4,0.23 \mathrm{~g}, 0.36 \mathrm{mmol})$ and $\operatorname{G1Br}(0.83 \mathrm{~g}, 2.17 \mathrm{mmol}), \mathbf{6 c}$ was obtained as a white solid $(0.98 \mathrm{~g}, 92 \%)$. ${ }^{1} \mathrm{H}$ NMR (200 MHz, $\mathrm{CDCl}_{3}$ ): $\delta=8.79$ (broad, 9H, overlapping $\mathrm{ArH}$ ), 7.6-7.0 (m, 60H, ArH), 6.94 (broad s, 16H, ArH), 6.63 (broad s, 8H, ArH), 5.4-4.5 (broad, 48H, overlapping $\left.\mathrm{ArCH}_{2}\right), 3.05$ (broad s, $\left.36 \mathrm{H}, \mathrm{N}\left(\mathrm{CH}_{3}\right)_{2}\right) ;{ }^{13} \mathrm{C}\left\{{ }^{1} \mathrm{H}\right\} \mathrm{NMR}$ $\left(50 \mathrm{MHz}, \mathrm{CDCl}_{3}\right): \delta=160.12,142.87,139.46,136.42$, $133.65(\mathrm{Ar}-\mathrm{C}) 130.14\left(\mathrm{~d}, \mathrm{Ar}-\mathrm{C},{ }^{2} J_{\mathrm{CP}}=13.3 \mathrm{~Hz}\right), 130.08-$ $127.96(\mathrm{~m}, \mathrm{Ar}-\mathrm{C}), 112.65,104.79(\mathrm{Ar}-\mathrm{C}) 70.61\left(\mathrm{OCH}_{2}\right)$, 67.02 (broad, $\left.\mathrm{CH}_{2} \mathrm{NCH}_{2}\right) 49.43\left(\mathrm{~N}\left(\mathrm{CH}_{3}\right)_{2}\right) ;{ }^{31} \mathrm{P}\left\{{ }^{1} \mathrm{H}\right\} \mathrm{NMR}$ $\left(81 \mathrm{MHz}, \mathrm{CDCl}_{3}\right): \delta=40.11$ (broad s); nano-ESI MS: $\mathrm{m} / \mathrm{z}$ 
$1388.68[\mathrm{M}-2 \mathrm{Br}]^{2+}(7 \%), 898.82\left[\mathrm{M}-3 \mathrm{Br}^{-}\right]^{3+}(56 \%)$, $654.37\left[\mathrm{M}-4 \mathrm{Br}^{-}\right]^{4+}(57 \%)$. Anal. calcd for $\mathrm{C}_{162} \mathrm{H}_{171} \mathrm{Br}_{6}{ }^{-}$ $\mathrm{N}_{6} \mathrm{O}_{12}$ PS: C 66.26, H 5.87, N 2.86, P 1.05. Found: C 66.18, H 5.98, N 2.91, P 1.06.

4.1.9. Synthesis of $\left[\mathrm{O}=\mathrm{P}(\mathrm{NCN})_{3} \cdot(\mathbf{G 2})_{6}\right] \mathrm{Br}_{6}(5 \mathrm{~d})$. Similar to the procedure described for 5c, starting from $\mathrm{O}=\mathrm{P}(\mathrm{NCN})_{3}(3,0.18 \mathrm{~g}, 0.29 \mathrm{mmol})$ and $\mathrm{G} 2 \mathrm{Br}(1.42 \mathrm{~g}$, $1.75 \mathrm{mmol}), \mathbf{5 d}$ was obtained as a white solid $(0.89 \mathrm{~g}$, $55 \%) .{ }^{1} \mathrm{H}$ NMR $\left(200 \mathrm{MHz}, \mathrm{CDCl}_{3}\right): \delta=9.0-8.6$ (broad, $9 \mathrm{H}$, overlapping $\mathrm{ArH}), 7.8-6.8$ (m, 120H, ArH), 6.64, 6.50, 6.47 (broad, 54H, overlapping ArH), 5.3-4.5 (broad, $84 \mathrm{H}$, overlapping $\left.\mathrm{ArCH}_{2}\right), 3.01$ (broad s, $\left.36 \mathrm{H}, \mathrm{N}\left(\mathrm{CH}_{3}\right)_{2}\right) ;{ }^{13} \mathrm{C}$ $\left\{{ }^{1} \mathrm{H}\right\} \mathrm{NMR}\left(50 \mathrm{MHz}, \mathrm{CDCl}_{3}\right): \delta=160.23,160.05,139.06$, 136.98, 136.53 (Ar-C), 128.79-127.87 (m, Ar-C), 112.55, $106.85,104.82,101.79(\mathrm{Ar}-\mathrm{C}), 70.25\left(\mathrm{OCH}_{2}\right), 67.50$ (broad, $\left.\mathrm{CH}_{2} \mathrm{NCH}_{2}\right), 49.38\left(\mathrm{~N}\left(\mathrm{CH}_{3}\right)_{2} ;{ }^{31} \mathrm{P} \quad\left\{{ }^{1} \mathrm{H}\right\} \quad \mathrm{NMR}\right.$ $\left(81 \mathrm{MHz}, \mathrm{CDCl}_{3}\right): \delta=25.24$ (broad s); nano-ESI MS: $\mathrm{m} / z$ $1742.71[\mathrm{M}-3 \mathrm{Br}]^{3+}(18 \%), 1286.57\left[\mathrm{M}-4 \mathrm{Br}^{-}\right]^{4+}(100 \%)$. Anal. calcd for $\mathrm{C}_{330} \mathrm{H}_{315} \mathrm{Br}_{6} \mathrm{~N}_{6} \mathrm{O}_{37} \mathrm{P}$ : C 72.49, H 5.81, N 1.54, P 0.57. Found: C 72.34, H 5.93, N 1.58, P 0.63.

4.1.10. Synthesis of $\left[S=P(N C N)_{3} \cdot(G 2)_{6}\right] B r_{6}(6 d)$. Similar to the procedure described for 5c, starting from $\mathrm{S}=\mathrm{P}(\mathrm{NCN})_{3} \quad(4,0.23 \mathrm{~g}, 0.36 \mathrm{mmol})$ and $\mathrm{G} 2 \mathrm{Br}(0.83 \mathrm{~g}$, $2.17 \mathrm{mmol})$, 6d was obtained as a white solid (0.98 g, 92\%). ${ }^{1} \mathrm{H}$ NMR $\left(200 \mathrm{MHz}, \mathrm{CDCl}_{3}\right): \delta=9.2-8.6$ (broad, 9H, overlapping $\mathrm{ArH}), 7.8-7.0(\mathrm{~m}, 120 \mathrm{H}, \mathrm{ArH}), 6.92,6.62$, 6.42 (broad, 54H, overlapping ArH), 5.3-4.4 (broad, 84H, overlapping $\left.\mathrm{ArCH}_{2}\right), 2.92$ (broad s, $\left.36 \mathrm{H}, \mathrm{N}\left(\mathrm{CH}_{3}\right)_{2}\right) ;{ }^{13} \mathrm{C}$ $\left\{{ }^{1} \mathrm{H}\right\} \mathrm{NMR}\left(50 \mathrm{MHz}, \mathrm{CDCl}_{3}\right): \delta=160.23,160.05,139.06$, 136.97 (Ar-C), 128.80-127.86 (m, Ar-C), 112.52, 106.75, 104.91, 101.87 (Ar-C), $70.23\left(\mathrm{OCH}_{2}\right), 67.51$ (broad, $\left.\mathrm{CH}_{2} \mathrm{NCH}_{2}\right), 49.46\left(\mathrm{~N}\left(\mathrm{CH}_{3}\right)_{2} ;{ }^{31} \mathrm{P}\left\{{ }^{1} \mathrm{H}\right\} \mathrm{NMR}(81 \mathrm{MHz}\right.$, $\mathrm{CDCl}_{3}$ ): $\delta=40.42$ (broad s); nano-ESI MS: $m / z \quad 1747.79$ $[\mathrm{M}-3 \mathrm{Br}]^{3+}(100 \%), 1290.69\left[\mathrm{M}-4 \mathrm{Br}^{-}\right]^{4+}(45 \%)$. Anal. calcd for $\mathrm{C}_{330} \mathrm{H}_{315} \mathrm{Br}_{6} \mathrm{~N}_{6} \mathrm{O}_{36} \mathrm{PS}$ : C 72.28, H 5.79, N 1.53, P 0.56. Found: C 72.20, H 5.71, N 1.60, P 0.61.

\subsection{Incorporation of $\mathrm{MO}$ in $\left[\mathrm{O}=\mathrm{P}(\mathrm{NCN})_{3} \cdot(\mathrm{G1})_{6}\right] \mathrm{Br}_{6}$ (5c)}

A previously reported procedure was applied, ${ }^{15}$ starting from a solution of $\mathbf{6 c}(0.36 \mathrm{~g}, 0.12 \mathrm{mmol})$ in $\mathrm{CH}_{2} \mathrm{Cl}_{2}$ $(50 \mathrm{~mL})$ and a solution of $\mathrm{MO}(0.24 \mathrm{~g}, 0.74 \mathrm{mmol})$ in $\mathrm{H}_{2} \mathrm{O}$ $(50 \mathrm{~mL})$. The two solutions were mixed and stirred vigorously for $5 \mathrm{~min}$, after which the layers were allowed to separate. An orange $\mathrm{CH}_{2} \mathrm{Cl}_{2}$ layer and a slightly yellow $\mathrm{H}_{2} \mathrm{O}$ layer were obtained. The organic layer was separated, washed with $\mathrm{H}_{2} \mathrm{O}$, dried over $\mathrm{Mg}_{2} \mathrm{SO}_{4}$, filtered, and evaporated to dryness, affording a bright orange solid $(0.51 \mathrm{~g}, 96 \%) .{ }^{1} \mathrm{H} \mathrm{NMR}\left(200 \mathrm{MHz}, \mathrm{CDCl}_{3}\right): \delta=9.0-8.6$ (broad, 9H, overlapping ArH), 8.0-7.6 (broad, 36H, overlapping $\operatorname{ArH}(\mathrm{MO}))$ 7.5-7.0 (m, 60H, ArH), 6.68 (overlapping s, 28H, ArH(MO), ArH), 6.54 (broad s, 8H, $\mathrm{ArH}$ ), 5.2-4.4 (broad, 48H, overlapping $\mathrm{ArCH}_{2}$ ), 3.03 (s, $\left.36 \mathrm{H}, \mathrm{NMe}_{2}(\mathrm{MO})\right), 3.05\left(\right.$ broad s, $\left.36 \mathrm{H}, \mathrm{N}\left(\mathrm{CH}_{3}\right)_{2}\right)$.

\subsection{Reduction of $6 \mathrm{c}$ to afford $\left.\left[\mathrm{P}(\mathrm{NCN})_{3} \cdot \mathrm{G1}\right)_{6}\right]_{O T f_{6}}(7)$}

To a solution of $\mathbf{6 c}(0.115 \mathrm{~g}, 0.039 \mathrm{mmol})$ in $\mathrm{CH}_{2} \mathrm{Cl}_{2}$ $(10 \mathrm{~mL})$ was added MeOTf $(0.15 \mathrm{~mL}, 1.3 \mathrm{mmol})$ and the mixture was stirred for $30 \mathrm{~min}$. After removal of all volatiles and washing with $\mathrm{Et}_{2} \mathrm{O}(2 \times 10 \mathrm{~mL}), \mathrm{HMPT}(0.18 \mathrm{~mL}$, $1.0 \mathrm{mmol}$ ) was added and the mixture was stirred for $1 \mathrm{~h}$. After removal of all volatiles, the product was precipitated twice from $\mathrm{CH}_{2} \mathrm{Cl}_{2}$ with $\mathrm{Et}_{2} \mathrm{O}$, affording a white solid $(0.095 \mathrm{~g}, 72 \%) .{ }^{1} \mathrm{H}$ NMR $\left(200 \mathrm{MHz}, \mathrm{CDCl}_{3}\right): \delta=8.18$ (broad, 6H, ArH), 8.00 (broad s, 3H, ArH), 7.5-7.0 (m, $60 \mathrm{H}, \mathrm{ArH}$ ), 6.65 (broad, 24H, overlapping ArH), 4.97 (broad s, 24H, $\mathrm{ArCH}_{2}$ ), 4.54, 4.36 (broad, 24H, overlapping $\left.\mathrm{ArCH}_{2}\right), 2.78$ (broad s, 36H, N($\left.\left(\mathrm{CH}_{3}\right)_{2}\right) ;{ }^{31} \mathrm{P}\left\{{ }^{1} \mathrm{H}\right\} \mathrm{NMR}$ $\left(81 \mathrm{MHz}, \mathrm{CDCl}_{3}\right): \delta=0.10$ (broad s).

\subsection{General procedure for the reduction of the hexacationic phosphine sulfides}

The phosphine sulfide $(\mathbf{6 a}-\mathbf{d})$ was refluxed in a 2:1 mixture of $\mathrm{MeOH}$ and $\mathrm{P}(n-\mathrm{Bu})_{3}$ for $16 \mathrm{~h}$. The mixture was concentrated by distilling off all volatiles, after which $\mathrm{Et}_{2} \mathrm{O}$ was added to afford the crude product as a light yellow or white precipitate. The $\mathrm{S}=\mathrm{P}(n-\mathrm{Bu})_{3}$ side product was removed by repeated precipitation of the product from $\mathrm{MeOH}$ with $\mathrm{Et}_{2} \mathrm{O}$.

4.4.1. Analysis of $\left[\mathrm{P}(\mathrm{NCN})_{3} \cdot \mathbf{M e}_{6}\right] \mathrm{I}_{\mathbf{6}}(\mathbf{8 a})$. Starting from $\mathbf{6 a}$ $(0.13 \mathrm{~g}, 0.087 \mathrm{mmol})$, to yield $0.11 \mathrm{~g} \mathbf{8 a}(86 \%) ;{ }^{1} \mathrm{H}$ NMR $\left(200 \mathrm{MHz}, \mathrm{D}_{2} \mathrm{O}\right): \delta=8.02\left(\mathrm{~d}, 6 \mathrm{H}, \mathrm{Ar}-\mathrm{H},{ }^{2} J_{\mathrm{HP}}=7.4 \mathrm{~Hz}\right), 7.73$ $(\mathrm{s}, 3 \mathrm{H}, \mathrm{Ar}-\mathrm{H}), 4.65\left(\mathrm{~s}, 12 \mathrm{H}, \mathrm{ArCH}_{2}\right), 3.24(\mathrm{~s}, 48 \mathrm{H}$, $\left.\mathrm{N}\left(\mathrm{CH}_{3}\right)_{3}\right) ;{ }^{13} \mathrm{C}\left\{{ }^{1} \mathrm{H}\right\}$ NMR $\left(50 \mathrm{MHz}, \mathrm{D}_{2} \mathrm{O}\right): \delta=140.44(\mathrm{~d}$, $\left.\mathrm{Ar}-\mathrm{C},{ }^{1} J_{\mathrm{CP}}=19.9 \mathrm{~Hz}\right), 139.08\left(\mathrm{~d}, \mathrm{Ar}-\mathrm{H},{ }^{2} J_{\mathrm{CP}}=13.1 \mathrm{~Hz}\right)$, $138.72(\mathrm{~s}, \mathrm{Ar}-\mathrm{C}), 129.68\left(\mathrm{~d}, \mathrm{Ar}-\mathrm{C},{ }^{3} J_{\mathrm{CP}}=7.3 \mathrm{~Hz}\right), 68.24(\mathrm{~s}$, $\left.\mathrm{ArCH}_{2}\right), 53.10\left(\mathrm{~s}, \mathrm{~N}\left(\mathrm{CH}_{3}\right)_{3}\right) ;{ }^{31} \mathrm{P}\left\{{ }^{1} \mathrm{H}\right\} \mathrm{NMR}(81 \mathrm{MHz}$, $\left.\mathrm{D}_{2} \mathrm{O}\right): \delta=-3.92(\mathrm{~s})$; nano-ESI MS: $\mathrm{m} / \mathrm{z} 601.23\left[\mathrm{M}-2 \mathrm{I}^{-}\right]^{2+}$ (23\%), $358.86\left[\mathrm{M}-3 \mathrm{I}^{-}\right]^{3+}(100 \%), 237.61\left[\mathrm{M}-4 \mathrm{I}^{-}\right]^{4+}$ $(75 \%)$.

4.4.2. Analysis of $\left[\mathrm{P}(\mathrm{NCN})_{3} \cdot \mathrm{Bz}_{6}\right] \mathrm{Br}_{6}(8 b)$. Starting from $6 b$ $(60 \mathrm{mg}, 0.036 \mathrm{mmol})$, to yield $51 \mathrm{mg} \mathbf{8 b}(88 \%) ;{ }^{1} \mathrm{H}$ NMR (200 MHz, $\left.\mathrm{CD}_{3} \mathrm{OD}\right): \delta=8.41\left(\mathrm{~d}, 6 \mathrm{H}, \mathrm{Ar}-\mathrm{H},{ }^{2} J_{\mathrm{HP}}=4.8 \mathrm{~Hz}\right)$, 7.88 (s, 3H, ArH), 7.8-7.4 (m, 30H, ArH), 4.78 (s, 12H, $\left.\mathrm{ArCH}_{2}\right), 4.72\left(\mathrm{~s}, 12 \mathrm{H}, \mathrm{ArCH}_{2}\right), 3.06\left(\mathrm{~s}, 36 \mathrm{H}, \mathrm{N}\left(\mathrm{CH}_{3}\right)_{2}\right) ;{ }^{13} \mathrm{C}$ $\left\{{ }^{1} \mathrm{H}\right\} \mathrm{NMR}\left(50 \mathrm{MHz}, \mathrm{CDCl}_{3}\right): \delta=140.08(\mathrm{~d}, \mathrm{Ar}-\mathrm{C}$, $\left.{ }^{2} J_{\mathrm{CP}}=20.9 \mathrm{~Hz}\right), 138.83(\mathrm{~s}, \mathrm{Ar}-\mathrm{C}), 133.43,$,130.74 (s, $\mathrm{Ar}-\mathrm{C}), 129.79$ (d, $\left.\mathrm{Ar}-\mathrm{C},{ }^{3} J_{\mathrm{CP}}=13.3 \mathrm{~Hz}\right), 129.07 \quad(\mathrm{~s}$, $\mathrm{Ar}-\mathrm{C}$ ), 127.69 (s, Ar-C), 67.64, 67.17 (s, $\left.\mathrm{ArCH}_{2}\right), 48.75$ $\left(\mathrm{s}, \mathrm{N}\left(\mathrm{CH}_{3}\right)_{2}\right) ;{ }^{31} \mathrm{P}\left\{{ }^{1} \mathrm{H}\right\}$ NMR: $\delta=-1.82$ (s); nano-ESI MS: $m / z \quad 735.17\left[\mathrm{M}-2 \mathrm{Br}^{-}\right]^{2+}(12 \%), 464.16\left[\mathrm{M}-3 \mathrm{Br}^{-}\right]^{3+}$ $(68 \%), 328.10\left[\mathrm{M}-4 \mathrm{Br}^{-}\right]^{4+}(100 \%)$.

4.4.3. Analysis of $\left[\mathrm{P}(\mathrm{NCN})_{3} \cdot(\mathrm{G1})_{6}\right] \mathrm{Br}_{6}(8 \mathrm{c})$. Starting from 6c $(0.10 \mathrm{~g}, 0.034 \mathrm{mmol})$, to yield $61 \mathrm{mg} \mathrm{8c}(62 \%) ;{ }^{1} \mathrm{H}$ NMR $\left(200 \mathrm{MHz}, \mathrm{CDCl}_{3}\right): \delta=8.39$ (broad, $9 \mathrm{H}$, overlapping $\mathrm{ArH}$ ), 7.7-7.1 (m, 60H, ArH), 7.00 (broad s, 16H, ArH), 6.62 (broad s, 8H, ArH), 5.3-4.5 (broad, 48H, overlapping $\mathrm{ArCH}_{2}$ ), 3.05 (broad s, $\left.36 \mathrm{H}, \mathrm{N}\left(\mathrm{CH}_{3}\right)_{2}\right) ;{ }^{13} \mathrm{C}\left\{{ }^{1} \mathrm{H}\right\} \mathrm{NMR}$ $\left(50 \mathrm{MHz}, \mathrm{CDCl}_{3}\right): \delta=160.08,136.45(\mathrm{Ar}-\mathrm{C}) 129.28-$ $127.96(\mathrm{~m}, \mathrm{Ar}-\mathrm{C}), 112.69,104.56(\mathrm{Ar}-\mathrm{C}), 70.49\left(\mathrm{OCH}_{2}\right)$,

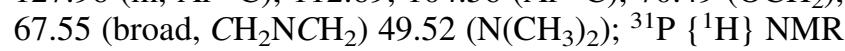
$\left(81 \mathrm{MHz}, \mathrm{CDCl}_{3}\right): \delta=-3.88($ broad s); nano-ESI MS, measured as the phosphine oxide: $\mathrm{m} / \mathrm{z} \quad 893.39$ $\left[\mathrm{M}_{\mathrm{ox}}-3 \mathrm{Br}^{-}\right]^{3+}(53 \%), 650.39\left[\mathrm{M}_{\mathrm{ox}}-4 \mathrm{Br}^{-}\right]^{4+}(41 \%)$.

4.4.4. Analysis of $\left[\mathbf{P}(\mathrm{NCN})_{3} \cdot(\mathbf{G 2})_{6}\right] \mathrm{Br}_{6}(8 \mathrm{~d})$. Starting from 6d $(0.25 \mathrm{~g}, 0.046 \mathrm{mmol})$, to yield $0.21 \mathrm{~g} \mathrm{8d}(84 \%) ;{ }^{1} \mathrm{H} \mathrm{NMR}$ $\left(200 \mathrm{MHz}, \mathrm{CDCl}_{3}\right): \delta=9.0-8.2$ (broad, $9 \mathrm{H}$, overlapping 
ArH), 7.6-7.0 (m, 120H, ArH), 6.89, 6.60, 6.41 (broad, 54H, overlapping $\mathrm{ArH}$ ), 5.3-4.4 (broad, 84H, overlapping $\left.\mathrm{ArCH}_{2}\right), 2.94$ (broad s, 36H, N $\left.\left(\mathrm{CH}_{3}\right)_{2}\right) ;{ }^{13} \mathrm{C}\left\{{ }^{1} \mathrm{H}\right\} \mathrm{NMR}$ $\left(50 \mathrm{MHz}, \mathrm{CDCl}_{3}\right): \delta=160.15,159.97,138.97,136.94$, 136.46 (Ar-C) 129.26-127.82 (m, Ar-C), 112.53, 106.80, 104.77, $101.83(\mathrm{Ar}-\mathrm{C}), 70.25\left(\mathrm{OCH}_{2}\right), 67.42$ (broad, $\left.\mathrm{CH}_{2} \mathrm{NCH}_{2}\right), 49.47\left(\mathrm{~N}\left(\mathrm{CH}_{3}\right)_{2} ;{ }^{31} \mathrm{P}\left\{{ }^{1} \mathrm{H}\right\} \quad \mathrm{NMR}\right.$ $\left(81 \mathrm{MHz}, \mathrm{CDCl}_{3}\right.$ ): $\delta=-3.83$ (broad s); nano-ESI MS: $\mathrm{m} / \mathrm{z}$ $1735.33\left[\mathrm{M}-3 \mathrm{Br}^{-}\right]^{3+}(79 \%), 1281.94\left[\mathrm{M}-4 \mathrm{Br}^{-}\right]^{4+}(67 \%)$.

\subsection{Computational details}

Geometry optimizations were performed on a molecular mechanics level using the SPARTAN 5.1.1 (UNIX) package, ${ }^{23}$ with a MMFF94 force field. The input data was derived from the builder routine in the package. Calculations on the rotation around the $\mathrm{P}-\mathrm{C}$ bonds were carried out using the coordinate driving routine in the package on a molecular mechanics level. The energy profiles of a rotation around $720^{\circ}$ were determined and for the barrier of such a rotation, the difference between minimum and maximum energy was taken. In these calculations, the individual aryl rings of the triarylphosphine core were forced in a planar geometry using the constrain dihedral option, to prevent deformations.

\section{Acknowledgements}

The authors like to acknowledge C. Versluis (Utrecht University, Department of Biomolecular Mass Spectrometry) for conducting the mass spectrometry experiments and Dr T. Visser (Utrecht University, Department of Inorganic Chemistry and Catalysis) for help with the IR measurements.

\section{References}

1. For general reviews on dendrimers see (a): Newkome, G. R.; Moorefield, C. N.; Vögtle, F. Dendrimers and Dendrons: Concepts, Syntheses and Applications; VCH: Weinheim, 2001. (b) Fischer, M.; Vögtle, F. Angew. Chem. Int. Ed. 1999, 38, 884-905. For a review on dendrimer applications see: (c) Bosman, A. W.; Janssen, H. M.; Meijer, E. W. Chem. Rev. 1999, 99, 1665-1688.

2. Recent reviews on dendrimers in catalysis: (a) Kreiter, R.; Kleij, A. W.; Klein Gebbink, R. J. M.; van Koten, G. Top. Curr. Chem. 2001, 217, 163-199. (b) Astruc, D.; Chardac, F. Chem. Rev. 2001, 101, 2991-3024. (c) van Heerbeek, R.;
Kamer, P. J. C.; van Leeuwen, P. W. N. M.; Reek, J. N. H. Chem. Rev. 2002, 102, 3717-3756.

3. For a review on phosphorus containing dendrimers: Majoral, J.-P.; Caminade, A.-M. Top. Curr. Chem. 1998, 197, 79-124.

4. De Groot, D.; Reek, J. N. H.; Kamer, P. C. J.; Van Leeuwen, P. W. N. M. Eur. J. Org. Chem. 2002, 6, 1085-1095.

5. Reetz, M. T.; Giebel, D. Angew. Chem Int. Ed. 2000, 39, 2498-2501.

6. Köllner, C.; Pugin, B.; Togni, A. J. Am. Chem. Soc. 1998, 120, 10274-10275.

7. Maraval, V.; Caminade, A-M.; Majoral, J.-P. Organometallics 2000, 19, 4025-4029.

8. (a) Hovestad, N. J.; Eggeling, E. B.; Heidbüchel, H. J.; Jastrzebski, J. T. B. H.; Kragl, U.; Keim, W.; Vogt, D.; van Koten, G. Angew. Chem. Int. Ed. 1999, 38, 1655-1658. (b) Wijkens, P.; Jastrzebski, J. T. B. H.; van der Schaaf, P.; Kolly, R.; Hafner, A.; van Koten, G. Org. Lett. 2000, 2, 1621-1624.

9. (a) Miedaner, A.; Curtis, C. J.; Barkley, R. M.; Dubois, D. L. Inorg. Chem. 1994, 33, 5482-5490. (b) Petrucci-Samija, M.; Guillemette, V.; Dasgupta, M.; Kakkar, A. K. J. Am. Chem. Soc. 1999, 121, 1968-1969.

10. Oosterom, G. E.; Steffens, S.; Reek, J. N. H.; Kamer, P. C. J.; Van Leeuwen, P. W. N. M. Top. Catal. 2002, 19, 61-73.

11. Brunner, H. J. Organomet. Chem. 1995, 500, 39-46.

12. Fan, Q-H.; Chen, Y-M.; Chen, X-M.; Jiang, D-Z.; Xi, F.; Chan, A. S. C. Chem. Commun. 2000, 789-790.

13. Catalano, V. J.; Parodi, N. Inorg. Chem. 1997, 36, 537-541.

14. Balaji, B. S.; Obora, Y.; Ohara, D.; Koide, S.; Tsuji, Y. Organometallics 2001, 20, 5342-5350.

15. Kleij, A. W.; van de Coevering, R.; Klein Gebbink, R. J. M.; Noordman, A. M.; Spek, A. L.; van Koten, G. Chem. Eur. J. 2001, 7, 181-192.

16. Van de Coevering, R.; Kuil, M.; Klein Gebbink, R. J. M.; van Koten, G. Chem. Commun. 2002, 1636-1637.

17. Steenwinkel, P.; James, S. L.; Grove, D. M.; Veldman, N.; Spek, A. L.; van Koten, G. Chem. Eur. J. 1996, 2, 1440-1445.

18. Hawker, C. J.; Fréchet, J. M. J. J. Am. Chem. Soc. 1990, 112, 7638-7647.

19. Gilbertson, S. R.; Collibee, S. E.; Agarkov, A. J. Am. Chem. Soc. 2000, 122, 6522-6523.

20. Tolman, C. A. Chem. Rev. 1977, 77, 313-348.

21. Bellamy, L. J. The Infra-red Spectra of Complex Molecules; Wiley: New York, 1975; pp 348-349, 360-361.

22. Aqueous-Phase Organometallic Chemistry; Concepts and Applications; Cornils, B., Herrman, W. A., Eds.; WileyVCH: Weinheim, 1998.

23. SPARTAN SGI version 5.1.1; Wavefunction Inc.: 18401 Von Karman Ave., Ste. 370 Irvine, CA 92612 USA. 